\title{
Paspalum L. (Poaceae: Panicoideae: Paniceae) no estado de Pernambuco, Brasil ${ }^{1}$
}

\author{
Jefferson Rodrigues Maciel ${ }^{2,4}$, Regina Célia de Oliveira ${ }^{3}$ e Marccus Alves ${ }^{2}$
}

Recebido em 25/04/2008. Aceito em 16/04/2009

RESUMO - (Paspalum L. (Poaceae: Panicoideae: Paniceae) no estado de Pernambuco, Brasil). No presente trabalho são tratadas as espécies de Paspalum que ocorrem no Estado de Pernambuco. O estudo foi baseado em trabalho de campo, com duração de dois anos, e em espécimes analisados em 18 herbários do Brasil. Foram registradas 32 espécies do gênero, classificadas em dois subgêneros: Paspalum subg. Paspalum, com 29 espécies e P. subg. Harpostachys (Trin.) S. Denham, com três espécies. Dentre as espécies confirmadas, apenas $P$. notatum não é nativa de Pernambuco. Dez espécies são novas citações para Pernambuco, sendo o registro de $P$. calliferum o primeiro para o Brasil. São fornecidas informações sobre relações taxonômicas, distribuição geográfica e uso econômico das espécies.

Palavras-chave: Paspalum, Taxonomia, Poaceae, Pernambuco, Brasil

ABSTRACT - (Paspalum L. (Poaceae: Panicoideae: Paniceae) in Pernambuco state, Brazil). In this paper is showed a taxonomic study of Paspalum species from Pernambuco. Morphological study was supported by fieldwork and analyses of specimens from 18 Brazilian herbaria. The genus is represented in Pernambuco by 32 species distributed with two subgenera: Paspalum subg. Paspalum and $P$. subg. Harpostachys, with 29 and three species, respectively. Only P. notatum is not native. Ten species are new from Pernambuco state and the occurrence of the P. calliferum is the first record to Brazil. Information about taxonomic relationships, geographic distribution and economic use are given.

Key words: Paspalum, Taxonomy, Poaceae, Pernambuco, Brazil

\section{Introdução}

Paspalum L.é um dos maiores gêneros da família Poaceae. Cerca de 330 táxons são nativos da América tropical e subtropical e alguns ocorrem no Velho Mundo. O gênero é caracterizado por suas espiguetas plano-convexas, distribuídas unilateralmente sobre a ráquis, aos pares ou isoladas compondo uma panícula racemosa de 1-muitos ramos e pela gluma superior abaxial à ráquis (Clayton \& Renvoize 1986; Souza-Chies et al.2006).

Dentre as diversas propostas de classificações infragenéricas para Paspalum, a mais utilizada tem sido a de Chase (1929) que o dividiu em dois subgêneros Ceresia e Paspalum, e diversos grupos informais de espécies, baseados em similaridades fenéticas. Denham (2005) transferiu as espécies de Thrasya Kunth e do grupo informal Decumbentes de Paspalum para P. subg. Harpostachys (Trin.) S. Denham. Quatro subgêneros são reconhecidos para Paspalum: $P$. subg. Anachyris Chase, P. subg. Ceresia (Pers.) Rchb., $P$. subg. Harpostachys (Trin.) S. Denham e $P$. subg. Paspalum, sendo este último o maior e dividido em cerca de 24 grupos informais (Chase 1929; Denham 2005).

Diversos trabalhos sobre as espécies da flora brasileira de Paspalum já foram publicados, mas poucos tratam especificamente de espécies da Região Nordeste do Brasil (Renvoize 1984; Nascimento \& Renvoize 2001). Tendo em vista essa lacuna, o presente trabalho apresenta um tratamento taxonômico das espécies de Paspalum que ocorrem em Pernambuco.

\section{Material e métodos}

O estudo foi baseado na análise de material herborizado e fresco. Foram realizadas diversas coletas em todas as regiões fitogeográficas do Estado de
Pernambuco no período de janeiro de 2006 a julho de 2007. Foram levantadas e estudadas as coleções do gênero depositadas nos herbários BOTU, CPATSA, CEN, HST, IBGE, ICN, IPA, JPB, MOSS, PACA, PEUFR, RB, SP, SPF, UB e UFP (Siglas conforme Holmgren et al. 2003, exceto CPATSA, Herbário da EMBRAPA Semi-Árido, e HST, Herbário Sérgio Tavares da Universidade Federal Rural de Pernambuco).

A descrição das espécies foi baseada na análise morfológica das estruturas sob estereomicroscópio e a terminologia morfológica em LonghiWagner (2001). Para o estudo de cada táxon foram empregados exemplares previamente identificados por especialistas e a literatura específica. O material selecionado indicado no texto segue o critério de um exemplar por zona fitogeográfica, de acordo com a classificação de Andrade-Lima (1960) e todo o material examinado neste trabalho está relacionado no Anexo I. Os dados da distribuição geográfica foram obtidos das coleções dos herbários, da análise do banco de dados do Missouri Botanical Garden e complementados com as informações de Denham (2005), Oliveira \& Valls (2001) e Zuloaga \& Morrone (2005).

\section{Resultados e discussão}

\section{Paspalum L.}

Anual ou perene, cespitosa, estolonífera, com ou sem rizoma. Colmo florífero ereto, decumbente, semiprostrado, prostrado ou inclinado; nós muitos ou 1-7 nós. Folhas concentradas na base ou regularmente distribuídas ao longo do colmo; bainha foliar glabra, pubescente, às vezes ou sempre pilosa; lígula membranosa; lâmina oblonga, linear, linear-lanceolada ou lanceolada, aguda ou acuminadas, estreitando-se ou não em direção à base, glabras, pubescentes, pilosas ou lanadas. Inflorescência com 1-70 ramos, alternos, subconjugados ou conjugados, inflorescência axilar ausente ou presente; ráquis glabra, com tricomas esparsos e escabra, foliácea. Espigueta elíptica, obdeltóide, oboval, oval, suborbiculares, orbiculares, escutiforme, côncavoconvexa, plano-convexa, aguda, apiculada, acuminada,

\footnotetext{
1 Parte da dissertação de mestrado do Primeiro Autor

2 Laboratório de Morfo-Taxonomia Vegetal, Universidade Federal de Pernambuco. Recife, PE, Brasil

3 Departamento de Ciências Vegetais, Universidade Federal Rural do Semi-Árido

4 Autor para correspondência: jeff.r.maciel@gmail.com
} 
obtusa, pareada ou solitária; gluma inferior presente ou ausente; gluma superior presente ou ausente, mais curta, mais longa, atingindo metade ou de mesmo comprimento que o antécio superior, glabra, pubescente, pilosa, tricomas esparsos, clavados (P. clavuliferum), globosos (P. orbiculatum), tuberculados ou em máculas douradas, 2-9-nervada, nervuras poucos ou evidentes, membranácea, cartácea, coriácea, fimbriada (P. fimbriatum); antécio inferior neutro ou estaminado, pálea ausente ou presente, lema inferior glabro, papiloso, com tricomas próximo a margem, pubescente, puberuloso ou piloso, tricomas clavados, globosos, tuberculados, sem nervuras aparentes, 2-7-nervado, nervuras pouco ou evidentes, membranoso, cartáceo ou coriáceo, sulcado ou plano; antécio superior oval, obdeltóide, oblongo, oboval, orbicular, suborbicular ou elíptico, acuminado, agudo ou obtuso, cartáceo ou coriáceo, estramíneo a vináceo, atropúpureo, alvo ou castanho-claro, brilhante ou opaco, liso, finamente papiloso, papiloso ou estriado, lema superior expandido, pálea superior côncava, lema superior com tufo de tricomas no ápice (P. distichum).

Chave para identificação das espécies de Paspalum de Pernambuco

1. Antécio superior castanho ou atro-purpúreo, brilhante ou opaco

2. Lígulas $0,5 \mathrm{~mm}$ compr.; ápice dos pedicelos com longos tricomas brancos ou dourados; gluma superior ausente 13. P. gardnerianum

2. Lígulas 0,8-4mm compr.; ápice dos pedicelos glabros; gluma superior presente

3. Colmos floríferos 120-170 cm compr.; inflorescências 11-18 ramos; ráquis esparsamente pilosas nas margens, escabras; espiguetas apiculadas

32. P. virgatum

3. Colmos floríferos 30-130cm compr.; inflorescências 2-9 ramos; ráquis glabras; espiguetas agudas ou obtusas

4. Espiguetas 1,9-2mm compr., suborbiculares a orbiculares.

15. P. melanospermum

4. Espiguetas 2-3mm compr., obdeltóides ou elípticas a obovais

5. Anuais; espiguetas obdeltóides, agudas; margem do lema superior expandida

6. P. convexum

5. Perenes; espiguetas elípticas a obovais, obtusas; margem do lema superior não expandida

6. Colmos floríferos eretos; lâminas foliares pilosas em toda a superfície ou só próximo à base; inflorescncias 6-9 ramos; nós 1-3; antécio superior 2,1-2,3 mm comp.

6. Colmos floríferos eretos ou decumbentes; lâminas foliares glabras ou escabras; inflorescências 3-7 ramos; nós 2-5; antécio superior 1,8-2,1 mm comp. 27. P. plicatulum

1. Antécio superior estramíneo ou alvo

7. Gluma superior com margens longo-ciliadas.

5. P. conjugatum

7. Gluma superior com margens não ciliadas

8. Gluma superior com tricomas sobre máculas douradas

1. P. arenarium

8. Gluma superior glabra, pubescente ou pilosa, mas sem máculas

9. Lema inferior sulcado longitudinalmente

10.Inflorescências 15-20 cm comp.; gluma superior pubescente

3. P. calliferum

10.Inflorescências 8-10,5 cm comp.; gluma superior glabra.

25. P. pilosum

9. Lema inferior plano

11.Espiguetas solitárias

12.Ráquis foliácea

29. P. repens

12.Ráquis não foliácea

13. Gluma superior com tricomas globosos

18. P. multicaule

13.Gluma superior glabra a pilosa, tricomas não globosos

14.Colmos floríferos prostrados; espiguetas $1 \mathrm{~mm}$ compr., orbiculares

22. P. orbiculatum

14.Colmos floríferos eretos ou decumbentes; espiguetas 1,7-3,1 mm compr., elípticas a ovais

15.Estoloníferas; folhas regularmente distribuídas ao longo do colmo; nós muitos

16. Gluma superior glabra

16.Gluma superior pubescente

15.Rizomatosas; folhas concentradas na base, nós 1-3.

17.Espigueta $1,7-2,1 \times 1-1,2 \mathrm{~mm}$.

17.Espigueta $3-3,1 \times 2-2,5 \mathrm{~mm}$

19. P. notatum

11.Espiguetas pareadas 
18.Gluma superior com tricomas clavados

4. P. clavuliferum

18.Gluma superior sem tricomas clavados

19.Gluma superior fimbriada

12. P. fimbriatum

19.Gluma superior não fimbriada

20.Espiguetas escutiformes

30. P. scutatum

20.Espiguetas elípticas, orbiculares a suborbiculares, ovais, obovais ou oblongas

21.Colmo florífero 7-10 cm compr.; espiguetas 0,8-1 mm compr.; gluma superior 2-nervada

24. P. parviflorum

21.Colmo florífero acima de $20 \mathrm{~cm}$ compr.; espiguetas 1,1-3mm compr.; gluma superior 2- 9-nervada 22.Plantas com rizomas longos; gluma superior

2-4-nervada 14. $P$. maritimum

22.Plantas sem rizomas ou com rizomas curtos; gluma superior 3-9-nervada

23.Lâmina foliar estreitando-se em direção à base

7. $P$. corcovadense

23.Lâmina foliar não se estreitando em direção à base

24.Ráquis com tricomas esparso

25.Espiguetas 1,1-1,5 mm compr., orbiculares a suborbiculares; gluma superior 3-5-nervada.

23. $P$. paniculatum

25.Espiguetas 1,8-2,1 mm compr., obovais a oblongas; gluma superior 3-nervada 26. Colmos floríferos até $70 \mathrm{~cm}$ compr.; inflorescências 6-16 ramos; espiguetas 1,8-2x0,9-1 mm, oblongas, apiculadas

9. $P$. denticulatum

26. Colmos floríferos 80-120 cm compr.; inflorescências 4-70 ramos; espiguetas $2-2,1 \times 2 \mathrm{~mm}$, obovais, obtusas 16. P. millegrana

24.Ráquis glabras

27.Gluma superior atingindo metade do comprimento do antécio superior

20. P. nutans

27.Gluma superior de mesmo comprimento ou mais estreita e mais curta que o comprimento do antécio superior, mas nunca atingindo metade do comprimento deste 28.Espiguetas obovais, gluma superior 5-9-nervada ......21. P. oligostachyum

28.Espiguetas elípticas, gluma superior 3-nervada

29.Gluma superior glabra

30.Inflorescências 5-8 ramos; lâminas foliares lineares; espiguetas 2-2,2 mm compr

26. P. pleostachyum

30.Inflorescências 2-3 ramos; lâminas foliares lanceoladas; espiguetas 2,3-2,5 mm compr. 11. P. divergens

29.Gluma superior pubescente ou pilosa 


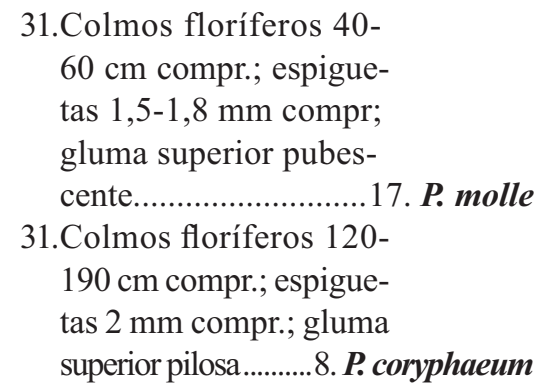

1. Paspalum arenarium Schrad., Mant. 2: 172. 1824.

Fig. 1

Perenes, cespitosas, rizomas curtos, superficiais. Colmos floríferos 40-70 cm compr., semi-prostrados a inclinados; nós 2-3. Folhas concentradas na base; bainhas foliares glabras, algumas vezes pilosas; lígulas $0,5-1 \mathrm{~mm}$ compr.; lâminas 2-8,5 $\times 0,6-1 \mathrm{~cm}$, lanceoladas, agudas ou acuminadas, não se estreitando em direção à base, glabras. Inflorescências com 1-2 ramos, 4-6 cm compr., alternos; inflorescências axilares presentes; ráquis glabras; ápice dos pedicelos glabros. Espiguetas 1,2-1,5x0,9-1,1 mm, obovais, plano-convexas, agudas, pareadas; gluma inferior ausente; gluma superior de mesmo comprimento do antécio superior, pubescente, tricoma sobre máculas douradas, 3-nervadas, nervuras inconspícuas, cartáceas; antécio inferior neutro, pálea ausente, lema inferior glabro ou pubescente, tricomas em máculas douradas, sem nervuras aparentes, cartáceo; antécio superior 1-1,3 x 0,8-0,9 mm, oboval, agudo, coriáceo, estramíneo, finamente papiloso ou liso.

Material selecionado: BRASIL. Pernambuco: Buíque, 5/VIII/2006, J.R. Maciel et al. 346 (IPA, UFP); Itapissuma, 13/IV/2006, J.R. Maciel et al. 154 (IPA, UFP).

Pertencente ao grupo informal Setacea, Paspalum arenarium tem como principal característica distintiva a presença de tricomas em máculas douradas na gluma superior. A espécie mais semelhante a $P$. arenarium é $P$. nutans Lam., a qual apresenta gluma superior glabra e sem máculas. Além disso, em $P$. nutans a gluma superior cobre metade do lema superior, enquanto em $P$. arenarium o lema superior, quando descoberto, expõe menos de $1 / 3$ de sua superfície. Ocorre desde as Guianas até o sul do Brasil e foi coletada em solos arenosos do litoral e raramente em paisagens de exceção da caatinga. Neste trabalho P. arenarium é registrada pela primeira vez para Pernambuco.

\section{Paspalum atratum Swallen, Phytologia 14:378. 1966.}

Fig. 2

Perenes, cespitosas, rizomas longos, profundos. Colmos floríferos 80-130 cm compr., eretos; nós 1-3. Folhas concentradas na base; bainhas foliares glabras; lígulas 1-2,1 mm compr.; lâminas 23-56x0,5-0,9 cm, lineares, agudas, não se estreitando em direção à base, pilosas em toda a superfície ou só próximo à base. Inflorescências com 6-9 ramos, 4-9 cm compr., alternos; inflorescência axilar ausente; ráquis glabras; ápice dos pedicelos glabros. Espiguetas 2,1-2,8x1,3$2 \mathrm{~mm}$, elípticas, plano-convexas, obtusas, pareadas; gluma inferior ausente; gluma superior de mesmo comprimento do antécio superior, glabra ou às veze com tricomas curtos, esparsos, 5-nervada, nervuras conspícuas, membranácea; antécio inferior neutro, pálea ausente, lema inferior glabro, 3-5-nervado, nervuras conspícuas, membranáceo; antécio superior 2,1-2,3×1,4-1,9 mm, elíptico, obtuso, coriáceo, atro-purpúreo, brilhante, finamente papiloso.

Material selecionado: BRASIL. Pernambuco: Recife, 23/ III/2006, J.R. Maciel \& D. Amorim 01 (IPA, UFP); São Lourenço da Mata, 18/IV/2006, J.R. Maciel et al. 166 (IPA, UFP).

Espécie muito semelhante a Paspalum plicatulum Michx., diferenciando-se pelo aspecto piramidal da inflorescência, na qual o ramo apical se destaca por ser mais longo que os demais. Seu potencial forrageiro deve ser alto uma vez que nas espécies do grupo Plicatula tais qualidades são tradicionalmente reconhecidas (Allem \& Valls 1987). Ocorre na Venezuela, Bolívia, Paraguai e Brasil, onde era conhecida para a Região Centro-Oeste e aqui é registrada pela primeira vez para Pernambuco. Foi coletada em borda de mata em solo úmido.

3. Paspalum calliferum S. Denham, Ann. Miss. Bot. Gard. 92: 501. 2005.

Fig. 3

Anuais, cespitosas, sem rizomas. Colmos floríferos 80-100 cm compr., eretos; nós 3 . Folhas concentradas na base; bainhas foliares glabras ou pilosas; lígulas 1,5 mm compr.; lâminas 15 $30 \times 0,3-0,7 \mathrm{~cm}$, linear-lanceoladas, agudas, não se estreitando em direção à base, glabras ou pilosas. Inflorescências com 1 ramo, $15-20 \mathrm{~cm}$ compr.; inflorescência axilar presente; ráquis glabras; ápice dos pedicelos glabros. Espiguetas 3,5-4x1,2$1,5 \mathrm{~mm}$, elípticas, plano-convexas, agudas, pareadas; gluma inferior presente; gluma superior de mesmo comprimento ou mais curta que o antécio superior, pubescente, 3-nervada, nervuras inconspícuas, cartácea; antécio inferior estaminado, pálea presente, lema inferior pubescente, 3-nervado, nervuras inconspícuas, cartáceo, sulcado longitudinalmente; antécio superior 3-3,1x1-1,3 mm, elíptico, agudo, coriáceo, estramíneo a vináceo, finamente papiloso.

Material selecionado: BRASIL: Pernambuco: Garanhuns, 18/VIII/1969, E.C. Tenório 803 (IPA); Quipapá, 18/ VIII/1966, E.B. Correia (IPA-15046). 
Pertence a Paspalum subg. Harpostachys, sendo caracterizada pelas espiguetas com gluma superior pubescente e lema inferior sulcado. Denham (2005) cita que a espécie mais afim a esta é Paspalum foliiforme S. Denham, com ocorrência no Brasil, e que os caracteres que as diferenciam são algumas vezes conflitivos e sobrepostos. A presença de tricomas em toda a extensão da gluma e do lema e a espigueta aguda, ao contrário do que ocorre com $P$. foliiforme, que apresenta gluma superior pubescente apenas na metade apical e espigueta apiculada, permite a diferenciação. Ocorre desde a Costa Rica até o Suriname, sendo que aqui é feito o primeiro registro desta espécie para o Brasil. Foi encontrada em solos arenosos do agreste. Seu potencial forrageiro é desconhecido.

\section{Paspalum clavuliferum C. Wright, Anales Acad. Ci. Med.} Habana 8: 203. 1871.

Fig. 4

Anuais, cespitosas, sem rizomas. Colmos florífero 35$50 \mathrm{~cm}$ compr., eretos; nós 3 . Folhas concentradas na base; bainhas foliares densamente pilosas, tricomas tuberculados; lígulas $1 \mathrm{~mm}$ compr.; lâminas $7-18 \times 0,2-0,4 \mathrm{~cm}$, lineares, agudas, não se estreitando em direção à base, densamente pilosas em ambas as faces. Inflorescências com 2-6 ramos, 4-7 cm compr., alternos; inflorescência axilar ausente; ráquis glabras; ápice dos pedicelos glabros. Espiguetas 1-1,1x0,6$0,8 \mathrm{~mm}$, elípticas a obovais, plano-convexas, agudas, pareadas ou solitárias na parte apical do ramo; gluma superior mais curta que o antécio superior, pilosa, tricomas clavados, 3-nervada, nervuras conspícuas, membranácea; antécio inferior neutro, pálea ausente, lema inferior glabro, 3-nervado, nervuras conspícuas, membranáceo; antécio superior $1 \times 0,8$ $\mathrm{mm}$, elíptico, agudo, estramíneo, coriáceo, papiloso.

Material selecionado: BRASIL. Pernambuco: Agrestina, 21/VI/2007, J.R. Maciel et al. 496 (MO, UFP); São Lourenço da Mata, V/1928, B. Pickel 1605 (IPA).

Pertencente ao grupo informal Parviflora, esta espécie se distingue das demais pelas espiguetas diminutas e pela presença de tricomas clavados na gluma superior. Distribuise desde o México até a Bolívia e Brasil, onde é encontrada em Alagoas, Bahia, Ceará, Distrito Federal, Goiás, Maranhão, Minas Gerais, Pará, Paraíba e Rio Grande do Norte. Foi coletada em bordas da Floresta Atlântica e Brejos de altitude em solos arenosos ou afloramentos rochosos. Não há informações quanto ao seu potencial como forrageira, mas o pequeno porte e pouca biomassa foliar não sugerem um valor forrageiro elevado. Paspalum clavuliferum não forma touceiras muito densas e é pouco comum em Pernambuco.

\section{Paspalum conjugatum Berg., Act. Helv. Phys.-Math. 7:} 129, pl. 8. 1762

Fig. 5

Perenes, cespitosas, rizomas longo, superficiais. Colmos florífero até $35 \mathrm{~cm}$ compr., eretos; nó 1 . Folhas concentradas na base; bainhas foliares glabras; lígulas $1 \mathrm{~mm}$ compr.; lâminas 2-15x0,4-0,9 cm, lanceoladas, agudas, não se estreitando em direção à base, glabras a pilosas em ambas as faces. Inflorescências com 2(-3) ramos, 6-11 cm compr., conjugados; inflorescência axilar ausente; ráquis glabras; ápice dos pedicelos glabros. Espiguetas 1,2-1,8x1-1,5 mm, ovais, côncavo-convexas, agudas, apiculadas ou acuminadas, solitárias; gluma superior mais longa que o antécio superior, glabra, margens longo-ciliadas, 2-nervada, nervuras conspícuas, membranácea; antécio inferior neutro, pálea ausente, lema inferior glabro, 2-nervado, nervuras conspícuas, a central ausente, membranáceo; antécio superior 1-1,5x0,8-1 $\mathrm{mm}$, oval, agudo, apiculado ou acuminado, cartáceo, estramíneo ou alvo, liso.

Material selecionado: BRASIL. Pernambuco: Bezerros, 9/IV/2005, J.R. Maciel et al. 24 (IPA); Bonito, XI/2003, J.R. Maciel \& W.C. da Silva 53 (IPA); Igarassu, 27/III/2006, J.R. Maciel 06 (IPA, UFP).

Do grupo informal Conjugata, pode ser facilmente reconhecida por seu longo rizoma, suas espiguetas ovais, 2-nervadas e com longos cílios nas margens da gluma superior. Ocorre amplamente desde os EUA até a Argentina. Barreto (1957) cita o valor forrageiro regular desta espécie e Dombrowski (1989) observa que $P$. conjugatum se constitui numa forrageira tenra e boa que cobre totalmente o pasto.

\section{Paspalum convexum Humb. \& Bonpl. ex Flüggé, Gram. Monogr., Paspalum 175. 1810. \\ Fig. 6}

Anuais, cespitosas, sem rizomas. Colmos floríferos 30-60 cm compr., eretos; nós 2-4. Folhas concentradas na base; bainhas foliares glabras ou pilosas próximo à margem; lígulas 1,5-2 mm compr.; lâminas 6,5-17x0,4-0,8 cm, linearlanceoladas, agudas, não se estreitando em direção à base, pilosas. Inflorescências com 2-3 ramos, 3-6 cm compr., alternos; inflorescência axilar ausente; ráquis glabras; ápice dos pedicelos glabros. Espiguetas 2-2,6x2-2,5 mm, obdeltóides, plano-convexas, agudas, pareadas; gluma superior de mesmo comprimento do antécio superior, glabra a levemente pubescente, 5-nervada, nervuras conspícuas, cartácea; antécio inferior neutro, pálea ausente, lema inferior glabro a pubescente na parte central, 5-nervado, nervuras conspícuas, cartáceo; antécio superior 2-2,5×2-2,3 mm, obdeltóide, agudo, coriáceo, atro-pupúreo, brilhante, finamente papiloso, lema superior com margens expandidas.

Material selecionado: BRASIL. Pernambuco: Arcoverde, 21/V/1980, L. Coradin et al. 2472 (CEN, IBGE, SP); Caruaru, 12/V/2007, J.R. Maciel 466 (MO, UFP); Igarassu, 6/IV/2006, J.R. Maciel 19 (UFP).

Paspalum convexum pertence ao grupo informal Plicatula e é caracterizada pela duração anual, a espigueta obdeltóide e a margem do lema superior expandida. Ocorre desde o México até a Bolívia e Brasil, onde se distribui nas Regiões Norte, Centro-Oeste e Nordeste até Minas Gerais. Foi encontrada em borda de mata, em solos úmidos. Aqui é 
feito o primeiro registro desta espécie para Pernambuco. A espécie mais semelhante na área de estudo é $P$. melanospermum, porém ambas se distinguem pelo tamanho e forma da espigueta. Segundo Pupo (1989), P. convexum é forrageira tenra e palatável, com boas qualidades para ser utilizada como pastagem ou na produção de feno.

7. Paspalum corcovadense Raddi, Agrostogr. Bras. 2: 2728. 1823.

Fig. 7

Perenes, cespitosas, rizomas curtos, superficiais. Colmos floríferos 30-80 cm compr., eretos; nós 2. Folhas concentradas na base; bainhas foliares glabras; lígulas $1 \mathrm{~mm}$ compr.; lâminas 8-18x0,6-1,1 cm, lanceoladas, agudas, estreitandose em direção à base, glabras. Inflorescências com 2-3 ramos, 8-9 cm compr., alternos; inflorescência axilar ausente; ráquis glabras; ápice dos pedicelos glabros. Espiguetas 2,8-3x1 mm, elípticas, plano-convexas, agudas, pareadas; gluma superior mais curta que o antécio superior, glabra, 3-nervada, nervuras inconspícuas, cartácea; antécio inferior neutro, pálea ausente, lema inferior glabro, 3-nervado, nervuras inconspícuas, cartáceo; antécio superior 2,1x0,8-1 mm, elíptico, agudo, cartáceo, estramíneo, liso, pálea superior côncava.

Material selecionado: BRASIL. Pernambuco: Paulista, 7/IV/1959, A. Sarmento 201 (IPA).

Pertencente ao grupo informal Corcovadensia, caracteriza-se pelo estreitamento da lâmina foliar em direção à bainha. Morfologicamente muito próxima das espécies do grupo Caespitosa (Barreto 1965), diferencia-se das espécies registradas em Pernambuco pelo aspecto único da folha e pelo tamanho da espigueta. Ocorre desde o México até Honduras, Venezuela, Guiana e Brasil, onde se distribui desde a Paraíba até o Rio Grande do Sul. Foi coletada em borda de mata.

\section{Paspalum coryphaeum Trin., Gram. Panic.: 114. 1826.} Fig. 8

Perenes, cespitosas, rizomas curtos, profundos. Colmos floríferos 120-190 cm compr., decumbentes; nós 1-3. Folhas concentradas na base; bainhas foliares glabras ou pilosas com tricomas tuberculados; lígulas $1 \mathrm{~mm}$ compr.; lâminas 12,5-56x0,6-1,2 cm, linear-lanceoladas, agudas, não se estreitando em direção à base, glabras ou pilosas. Inflorescências com 8-40 ramos, 3-15 cm compr., alternos; inflorescência axilar ausente; ráquis glabras; ápice dos pedicelos glabros. Espiguetas $2 \times 1 \mathrm{~mm}$, elípticas, plano-convexas, agudas, pareadas; gluma superior mais estreita, de mesmo comprimento ou mais curta que o antécio superior, pilosa, tricomas tuberculados, 3-nervada, nervuras conspícuas, membranácea; antécio inferior neutro, pálea ausente, lema inferior glabro, raramente piloso, tricomas tuberculados, 3-nervado, nervuras conspícuas, a central presente, membranáceo; antécio superior 1,8-2x0,9-1 mm, elíptico, agudo, coriáceo, estramíneo, finamente papiloso.
Material selecionado: BRASIL. Pernambuco: Bodocó, 22/V/1980, L. Coradin et al. 2500 (CEN); São Lourenço da Mata,V/1928, B. Pickel 1561 (IPA).

Paspalum coryphaeum pertence ao grupo informal Quadrifaria e se caracteriza por apresentar gluma superior pilosa com tricomas tuberculados. Barreto (1966) também ressalta a presença de tricomas tuberculados na espigueta para diferenciar P. coryphaeum das espécies afins. O autor ainda destaca o colmo decumbente como importante caráter diagnóstico. No entanto, este é mais difícil de visualizar em material herborizado. Ocorre no Panamá, Trinidad, Guianas até o Brasil, onde tem registro no Pará, e nas regiões CentroOeste, Sudeste e Nordeste. Foi coletada em borda de mata no litoral. Segundo Barreto (1966), as espécies deste grupo não são forrageiras de valor.

9. Paspalum denticulatum Trin., Gram. Panic. 111. 1826. Fig. 9

Perenes, cespitosas, sem rizomas. Colmos floríferos até $70 \mathrm{~cm}$ compr., eretos; nós 7 . Folhas concentradas na base; bainhas foliares glabras; lígulas $2 \mathrm{~mm}$ compr.; lâminas $10-40 \times 0,2-0,3 \mathrm{~cm}$, lineares, agudas, não se estreitando em direção à base, glabras. Inflorescências com 6-16 ramos, 1-2 $\mathrm{cm}$ compr., alternos; inflorescência axilar ausente; ráquis escabra e com tricomas longos; ápice dos pedicelos glabros. Espiguetas 1,8-2x0,9-1 mm, oblongas, plano-convexas, apiculadas, pareadas; gluma superior de mesmo comprimento do lema inferior, pubescente, 3-nervada, nervuras conspícuas, membranácea; antécio inferior neutro, pálea ausente, lema inferior puberuloso, 3-nervado, nervuras conspícuas; antécio superior 1,7-1,9x0,9-1 mm, oboval a oblongo, obtuso, coriáceo, estramíneo, papiloso.

Material selecionado: BRASIL. Pernambuco: Belém do São Francisco, 20/VII/1967, E.C. Tenório 337 (IPA).

Paspalum denticulatum pertence ao grupo Livida e é facilmente caracterizada por sua inflorescência de ramos muito curtos e numerosos. Além disso, a ráquis escabra e com longos tricomas esparsos e a espigueta oblonga, são outros caracteres distintivos. Paspalum denticulatum é completamente distinta das demais espécies de Paspalum tratadas neste trabalho, e pelo aspecto da inflorescência pode ser confundida com Echinochloa P. Beauv. Ocorre amplamente desde os EUA até o Norte da Argentina. Neste trabalho a espécie é registrada pela primeira vez para Pernambuco. Foi coletada na caatinga, em solo úmido. Seu potencial forrageiro é desconhecido.

10. Paspalum distichum L., Syst. Nat., ed. 10, 2: 855. 1759. Fig. 10

Perenes, estoloníferas. Colmos floríferos até $30 \mathrm{~cm}$ compr., eretos; nós muitos. Folhas regularmente distribuídas ao longo do colmo; bainhas foliares glabras; lígulas $3 \mathrm{~mm}$ compr.; lâminas 2,5-15x0,2-0,6 cm, lanceoladas a lineares, agudas, não se estreitando em direção à base, glabras. Inflo- 
rescências com 2(3) ramos, 3,5-5 cm compr., subconjugados; inflorescência axilar ausente; ráquis glabras a curtamente escabras; ápice dos pedicelos glabros. Espiguetas 2,8-3x1,4$1,7 \mathrm{~mm}$, elípticas, plano-convexas, agudas a acuminadas, solitárias; gluma superior mais longa que o antécio superior, 3-5-nervada, nervuras conspícuas ou inconspícuas, cartácea, pubescente; antécio inferior neutro, pálea ausente, lema inferior glabro, 5-nervado, nervuras conspícuas ou não, cartáceo; antécio superior 2-2,5x1-1,1 mm, elíptico, acuminado a agudo, coriáceo, estramíneo, estriado, lema superior com tufo de tricomas no ápice.

Material selecionado: BRASIL. Pernambuco: São Caetano, 21/V/1980, L. Coradin et al. 2467 (IPA, SP).

Pertencente ao grupo informal Disticha esta espécie pode ser reconhecida pelo hábito estolonífero, entrenós curtos do caule aéreo e espigueta aguda a acuminada. Porém, $P$. distichum guarda afinidade morfológica com Paspalum vaginatum $\mathrm{Sw}$. Em $P$. distichum a gluma superior é glabra, enquanto em $P$. vaginatum é pubescente. Além disso, as espiguetas em $P$. vaginatum medem 3-3,1mm compr., e possuem ápice acuminado e as espiguetas de $P$. distichum são menores e possuem ápice agudo ou acuminado. Ocorre amplamente em regiões subtropicais e tropicais do mundo. No Brasil está distribuída em praticamente todo o país. Foi coletada na caatinga em solos arenosos e úmidos. Smith et al. (1982) citam esta espécie como forragem de baixa produtividade e pouco apetecida.

\section{Paspalum divergens Döll, Fl. Bras. 2(2): 71. 1877.} Fig. 11

Perenes, cespitosas, rizomas curtos, profundos. Colmos florífero 50-100 cm compr., eretos; nós 3-5. Folhas concentradas na base; bainhas foliares glabras; lígulas $1 \mathrm{~mm}$ compr.; lâminas 7-15x0,4-0,7 cm, lanceoladas, agudas, não se estreitando em direção à base, glabras. Inflorescências com 2-3 ramos, 4-10 cm compr., alternos a subconjugados; inflorescência axilar ausente; ráquis glabras; ápice dos pedicelos glabros. Espiguetas 2,3-2,5x1,1-1,2 mm, elípticas, plano-convexas, agudas, pareadas; gluma inferior presente na maioria das espiguetas; gluma superior mais longa que o antécio superior, glabra, 3-nervada, nervuras conspícuas, cartácea; antécio inferior neutro, pálea ausente, lema inferior glabro, 3-nervado, nervuras conspícuas, cartáceo; antécio superior $2 \times 1 \mathrm{~mm}$, elíptico, agudo, coriáceo, estramíneo, papiloso.

Material selecionado: BRASIL: Pernambuco: Goiana, 12/VIII/2007, J.R. Maciel et al. 525 (UFP, MO); Olinda, 12/ IV/1935, B. Pickel 3773 (IPA).

Paspalum divergens pertence ao grupo Caespitosa e sempre foi conhecida apenas pelo material-tipo, coletado na Bahia (Renvoize 1984). Aparentemente restrita ao Nordeste do Brasil (Bahia, Pernambuco e Rio Grande do Norte), onde é encontrada em solos arenosos de restinga próximos a mangues. Aqui se faz o primeiro registro desta espécie para Pernambuco e se adicionam mais dois materiais para a sua coleção. Chase (dados não publicados) cita uma coleta da costa sul do Recife, que concorda parcialmente com a descrição original da espécie, diferindo pela presença de colmos floríferos não geniculados.

12. Paspalum fimbriatum Kunth, Nov. Gen. Sp. ed. 4, 1: 93 pl. 28. 1815 [1816].

Fig. 12

Anuais, cespitosas, sem rizomas. Colmos floríferos 40-100 cm, eretos; nós 2-5. Folhas concentradas na base; bainhas foliares glabras a pilosas; lígulas ca $2 \mathrm{~mm}$ compr.; lâminas 4,5-22x0,6-1,5 cm, lineares a lanceoladas, agudas, não se estreitando em direção à base, pilosas em ambas as faces, tricomas tuberculados. Inflorescências com 3-9 ramos, 2,5-8 cm compr., alternos; inflorescência axilar ausente; ráquis glabras; ápice dos pedicelos glabros. Espiguetas (2)3-3,6x(2)2,9-4 mm, ovais, côncavo-convexas, apiculadas, pareadas; gluma superior maior que o antécio superior, papilosa, 3-nervada, nervuras conspícuas, coriácea, fimbriada; antécio inferior neutro, pálea ausente, lema inferior papiloso, 3-nervado, coriáceo; antécio superior 2-2,2×1,5-1,9 mm, oval, obtuso, coriáceo, estramíneo, liso.

Material selecionado: BRASIL. Pernambuco: Afrânio, 20/IV/1971, E.P. Heringer et al. 209 (IPA, SP); Mirandiba, 30/III/2006, J.R. Maciel et al. 130 (UFP, IPA).

Espécie caracterizada muito facilmente pelas distintas fímbrias que se prolongam da gluma superior e conferem um aspecto peculiar tanto à inflorescência quanto à espigueta. Chase (dados não publicados) reuniu esta espécie com Paspalum scutatum Nees e Paspalum expansum Nees, em um grupo que nomeou de Fimbriata. Ocorre desde os EUA (Flórida), América Central, Colômbia, Venezuela e Guianas até o Brasil, onde seus registros se limitam ao Nordeste. É típica da caatinga, sendo encontrada em solos arenosos. É muito resistente ao pisoteio e quando submetida a este, adquire hábito prostrado, porém normalmente apresenta-se como ereta de colmos floríferos longos. Aparentemente não é procurada pelo gado, razão pela qual se crê que não possua grandes potenciais como forrageira.

\section{Paspalum gardnerianum Nees, Hooker's J. Bot. Kew} Gard. Misc. 2: 103. 1850.

Fig. 13

Perenes, cespitosas, rizomas curtos, profundos. Colmos floríferos 80-100 cm compr., eretos, nós. Folhas concentradas na base; bainhas foliares glabras ou densamente pilosas; lígulas $0,5 \mathrm{~mm}$ compr.; lâminas 5,5-15x0,4-0,8 $\mathrm{cm}$, lanceoladas, agudas a acuminadas, não se estreitando em direção à base, pilosas. Inflorescências 4-5 ramos, 5,5 $\mathrm{cm}$ compr., alternos; inflorescência axilar ausente; ráquis com tricomas esparsos; ápice com longos tricomas brancos ou dourados. Espiguetas 1,5-2x0,8-1 mm, elípticas, planoconvexas, agudas, pareadas; glumas inferior e superior au- 
sentes; antécio inferior neutro, pálea ausente, lema inferior glabro, 2-3 nervado, nervuras inconspícuas, membranácea; antécio superior 1,3-2x0,5-1 mm, oboval, agudo, coriáceo, castanho-claro, opaco, papiloso.

Material selecionado: BRASIL. Pernambuco: Itambé, 26/X/1966, E. C. Tenório 733 (IPA); Jaboatão dos Guararapes, 1/III/1931, B. Pickel 2559 (IPA).

Caracterizada pela ausência de ambas as glumas e pelos tricomas alvos ou dourados e longos no ápice dos pedicelos, Paspalum gardnerianum foi colocada no grupo Gardneriana por Chase (1929). Em Pernambuco nenhuma espécie compartilha características morfológicas que possam ser confundidas com P. gardnerianum. Ocorre desde o Panamá até o Paraguai, no Brasil é encontrada em quase todo o país, mas é citada pela primeira vez para Pernambuco neste trabalho. Foi coletada em tabuleiros costeiros e solos arenosos da restinga. Filgueiras (1992) indicou esta espécie como de alto valor forrageiro e com ótima palatabilidade nos pastos nativos do cerrado, onde é muito freqüente.

14. Paspalum maritimum Trin., Mém. Acad. Imp. Sci. Saint-Pétersbourg, Sér. 6, Sci. Math., Seconde Pt. Sci. Nat. 1: 148. 1834.

Fig. 14

Perenes, cespitosas, rizomas longos, superficiais. Colmos floríferos 50-100 cm compr., eretos a semi-prostrados, nós 2-3. Folhas concentradas na base; bainhas foliares glabras; lígulas $2 \mathrm{~mm}$ compr.; lâminas $6-42 \times 0,5-1,9 \mathrm{~cm}$, lineares a lanceoladas, agudas, não se estreitando em direção à base, glabras. Inflorescências com 4-9 ramos, 2,5-10 cm compr., alternos; inflorescência axilar presente; ráquis glabra; ápice dos pedicelos glabros. Espiguetas 1,8-2x0,9-1 mm, elípticas, plano-convexas, agudas, pareadas; gluma superior de mesmo comprimento ou mais curta que o antécio superior, pubescente, tricomas tuberculados, 2-4-nervada, nervuras inconspícuas, membranácea; antécio inferior neutro, pálea ausente, lema inferior glabro, 2-3-nervado, nervuras inconspícuas, membranáceo; antécio superior 1,9-2x0,8-1,3 mm, elíptico, agudo, coriáceo, estramíneo, finamente papiloso.

Material selecionado: BRASIL. Pernambuco: Buíque, 19/IX/1969, E.C. Tenório 1128 (IPA); Fernando de Noronha, 21/X/1955, D. Andrade-Lima 2236 (IPA); Goiana, 18/I/1970, J.F.M. Valls 1080 (ICN); Igarassu, 6/IV/2006, J.R. Maciel 124 (UFP, MO); Itamaracá, 18/II/1969, E.C. Tenório 674 (IPA); Itapissuma, 13/IV/2006, J.R. Maciel et al.156 (UFP, MO).

Pertencente ao grupo Paniculata, Paspalum maritimum é uma espécie caracterizada pelos longos rizomas. Dentre as espécies de Pernambuco, a que mais se aproxima de P. maritimum é P. pleostachyum Döll, mas essa última se diferencia por apresentar gluma superior glabra e pelos rizomas curtos. Ocorre desde a Venezuela até o Sul do Brasil. Foi coletada em bordas de mata e na restinga em solos arenosos. Smith et al. (1982) fazem referência aos colmos floríferos palatáveis, folhas abundantes e à resistência da planta ao pisoteio, fogo e seca, sendo apreciada pelos animais, enquanto nova. A partir das observações de campo feitas neste trabalho, pode se confirmar a resistência da planta e o seu vigor, sobretudo nos campos de restinga.

15. Paspalum melanospermum Desv. ex Poir., Encycl., Suppl. 4: 315. 1816.

Fig. 15

Anuais, cespitosas, sem rizomas. Colmos floríferos 30$60 \mathrm{~cm}$ compr., eretos; nós 1-4. Folhas concentradas na base; bainhas foliares glabras; lígulas 1-3 mm compr.; lâminas 12-49x0,3-1,3 cm, lineares a linear-lanceoladas, agudas, não se estreitando em direção a base, glabras ou pilosas próximo a margem ou na face adaxial. Inflorescências com (1-2)3-8 ramos, 2-8 cm compr., alternos; inflorescência axilar ausente; ráquis glabras; ápice dos pedicelos glabros. Espiguetas 1,92x1,7-2 mm, suborbiculares a orbiculares, plano-convexas, obtusas, pareadas; gluma superior mesmo comprimento do antécio superior, glabra a pubescente, 5-7-nervada, nervuras conspícuas, membranácea; antécio inferior neutro, pálea ausente, lema inferior glabra ou pubescente, 5-nervada, nervuras conspícuas, membranácea; antécio superior 1,82x1,7-2 mm, orbicular a suborbicular, obtuso, coriáceo, atro-purpúreo, brilhante, finamente papiloso.

Material selecionado: BRASIL. Pernambuco: Mirandiba, 30/III/2006, J.R. Maciel et al. 131 (UFP, IPA)

Diferenciada das outras espécies do grupo Plicatula pelas espiguetas suborbiculares a orbiculares. No material examinado notou-se uma grande variação no tamanho dos indivíduos e no número de ramos, o que pode estar associado à estação do ano e ao ambiente onde foram coletadas. Por ser uma planta anual e com ciclo de vida curto, normalmente os espécimens coletados podem estar em estádios muito jovens. Isto pode explicar por que uma das amostras apresentou apenas um ramo na inflorescência, condição atípica para a espécie. Ocorre desde as Antilhas, Norte da América do Sul até a Bolívia e Brasil. Foi coletada principalmente na caatinga, em solos arenosos ou em leitos de rios temporários, mas pode ser encontrada em bordas de mata no litoral.

\section{Paspalum millegrana Schrad., Mant. 2: 175. 1824.}

\section{Fig. 16}

Perenes, cespitosas, rizomas longos, profundos. Colmos florífero 80-120 cm compr., eretos; nós 3. Folhas concentradas na base; bainhas foliares glabras; lígulas $2 \mathrm{~mm}$ compr.; lâminas 40x1,2 cm, lineares, agudas, não se estreitando em direção a base, glabras. Inflorescências com 4-70 ramos, 5-10 cm compr., alternos; inflorescência axilar ausente; ráquis escabras e com tricomas esparsos; ápice dos pedicelos glabros. Espiguetas 2-2,1 $\times 2 \mathrm{~mm}$, obovais, plano-convexas, obtusas, pareadas; gluma superior do mesmo comprimento do antécio superior, glabra, 3-nervada, nervuras conspícuas, cartácea; antécio inferior neutro, pálea ausente, lema inferior glabro, 


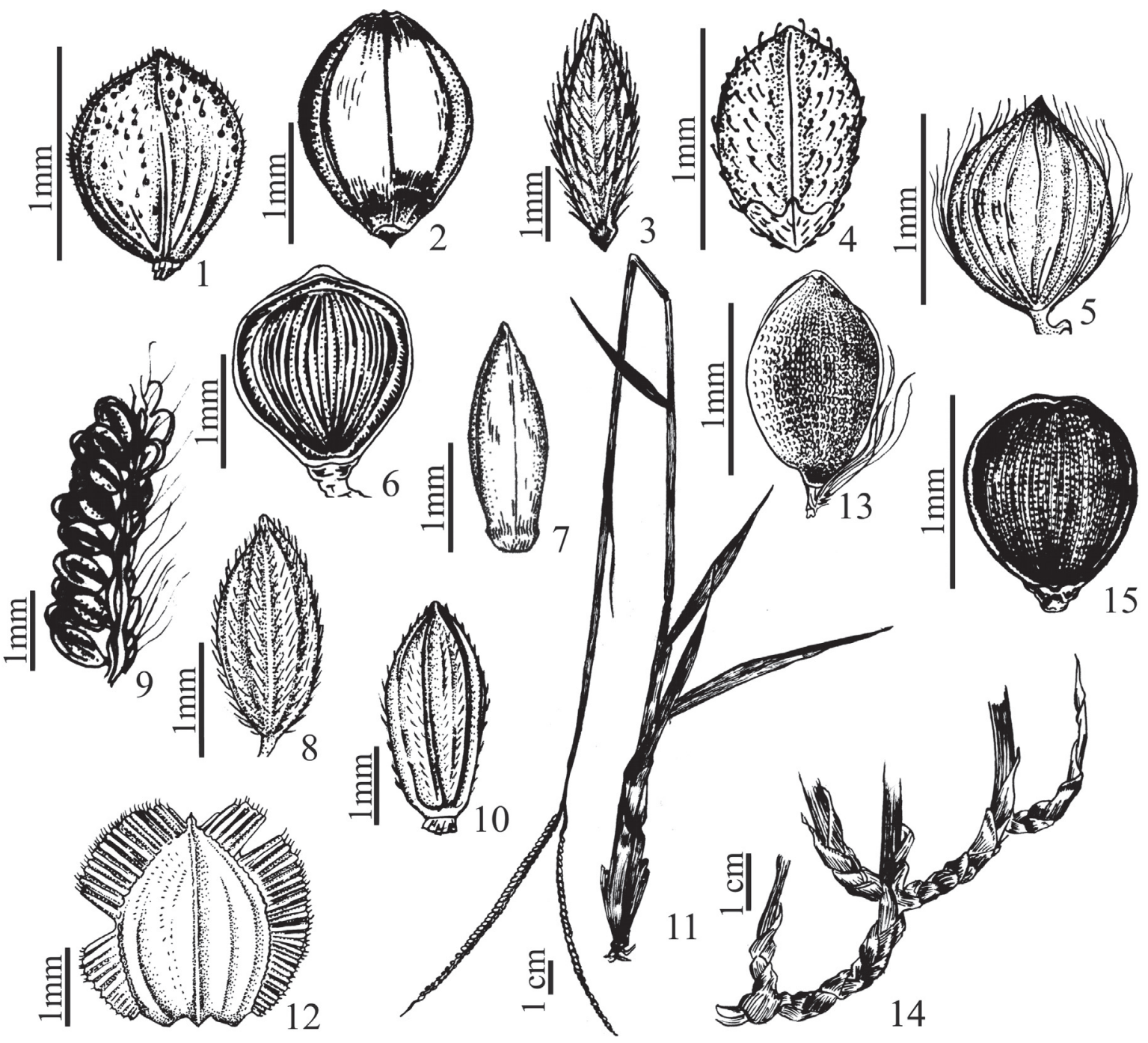

Figuras 1-15. Espigueta em vista da gluma superior: 1. Paspalum arenarium Schrad. (E.C. Tenório 887). 2. Paspalum atratum Swallen (J.R. Maciel 369). 3. Paspalum calliferum S. Denham (E.C. Tenório 803). 4. Paspalum clavuliferum C. Wright (Andrade-Lima et al. 9232). 5. Paspalum conjugatum Berg. (J.R. Maciel et al. 24). Antécio superior em vista da pálea: 6. Paspalum convexum Humb. \& Bonpl. ex Flüggé (E.C. Tenório 139). Espigueta em vista da gluma superior: 7. Paspalum corcovadense Raddi (A. Sarmento 201). 8. Paspalum coryphaeum Trin. (B. Pickel 2969). Aspecto da ráquis: 9. Paspalum denticulatum Trin. (E.C. Tenório 332). Espigueta em vista da gluma superior: 10. Paspalum distichum L. (L. Coradin et al. 2467). Hábito: 11. Paspalum divergens Döll (B. Pickel 3773). Espigueta em vista da gluma superior: 12. Papalum fimbriatum Kunth (J.R. Maciel et al. 130). Espigueta em vista do lema superior: 13. Paspalum gardnerianum Nees (B. Pickel 2559). Rizoma: 14. Paspalum maritimum Trin. (J.R. Maciel et al. 153). Antécio superior em vista da pálea: 15. Paspalum melanospermum Desv. ex Poir. (H.P. Heringer et al. 445)

3-nervado, nervuras conspícuas, cartáceo; antécio superior 1,8-2x1,7-1,8 mm, oboval, obtuso, coriáceo, estramíneo, finamente papiloso.

Material selecionado: BRASIL. Pernambuco: Igarassu, 6/VI/2006, J.R. Maciel 18 (IPA, UFP); Recife, 20/XII/2006, J.R. Maciel et al. 377 (UFP); Rio Formoso, 22/II/1971, E.C. Tenório 1212 (IPA).

Espécie de grande porte, com colmos floríferos robustos formando touceiras densas e tipicamente caracterizadas pela inflorescência piramidal com muitos ramos, a espigueta oboval de 2-2,1 $\mathrm{mm}$ de comprimento e gluma superior glabra. Também é muito característico na espécie o ramo mais basal da inflorescência superar os demais em comprimento. Se- gundo Barreto (1966), pertence ao grupo Quadrifaria. Ocorre amplamente desde os EUA até o Brasil, onde se distribui nas regiões Norte, Nordeste e Sudeste. Foi coletada em bordas de mata ou beira de estradas. Seu potencial forrageiro é tido como de qualidade regular, sendo procurada pelos animais na ausência de melhores pastagens (Smith et al. 1982).

\section{Paspalum molle Poir., Encycl. 5: 34. 1804.} Fig. 17

Perenes, cespitosas, rizomas curtos, superficiais. Colmos floríferos 40-60 cm compr., eretos; nós 2. Folhas concentradas na base; bainhas foliares glabras; lígulas $1 \mathrm{~mm}$ compr.; lâminas 4-28x0,3-0,8 cm, linear-lanceoladas, agudas, não se 
estreitando em direção à base, glabras. Inflorescências com (2-)3-11 ramos, 2,5-7,5 cm compr., alternos; inflorescência axilar ausente; ráquis glabras; ápice dos pedicelos glabros. Espiguetas 1,5-1,8x0,6-1 mm, elípticas, plano-convexas, agudas, pareadas; gluma superior de mesmo comprimento do antécio superior, pubescente, 3-nervada, nervuras conspícuas, membranácea; antécio inferior neutro, pálea ausente, lema inferior glabro ou com tricomas próximo a margem, 3-nervado, nervuras conspícuas, membranáceo; antécio superior 1,3-1,8x0,5-0,9 mm, elíptico, agudo, coriáceo, estramíneo, finamente papiloso, pálea superior côncava.

Material selecionado: BRASIL. Pernambuco: Angelim, 18/VIII/1969, E.C. Tenório 759 (IPA); Caruaru, 12/V/2007, J.R. Maciel et al. 458 (IPA); São Lourenço da Mata, 18/ IV/2006, J.R. Maciel et al. 172 (IPA, UFP).

Paspalum molle pertence ao grupo Caespitosa. As plantas desta espécie possuem pequeno porte, espiguetas elípticas com 1,5-1,8 mm de comprimento e pedicelos de mesmo comprimento ou mais longos que a espigueta. Ocorre no Caribe, Venezuela e Brasil, onde tem registros em Alagoas, na Bahia, Paraíba, em Pernambuco e no Rio Grande do Sul. Foi coletada em borda de mata e brejos de altitude em afloramentos rochosos. Não há informações quanto ao seu potencial forrageiro.

18. Paspalum multicaule Poir. Encycl., Suppl. 4: 309. 1816. Fig. 18

Anuais, cespitosas, sem rizomas. Colmos florífero 20$30 \mathrm{~cm}$ compr., eretos; nós 3 . Folhas concentradas na base; bainhas foliares glabras; lígulas $0,6 \mathrm{~mm}$ compr.; lâminas $4,5-15 \times 0,3 \mathrm{~cm}$, lineares, agudas, não se estreitando em direção à base, densamente pilosas. Inflorescências com 2 ramos, 2-4,5 cm compr., subconjugados; inflorescência axilar ausente; ráquis glabras; ápice dos pedicelos glabros. Espiguetas 1,2x1 mm, orbiculares, plano-convexas, obtusas, solitárias; gluma superior do mesmo comprimento do antécio superior, pilosa, tricomas globosos, 3-nervada, nervuras conspícuas, membranácea; antécio inferior neutro, pálea ausente, lema inferior piloso, tricomas globosos, 3-nervado, nervuras conspícuas, plano, membranáceo; antécio superior 1x1 mm, orbicular, obtuso, coriáceo, estramíneo, papiloso.

Material selecionado: BRASIL. Pernambuco: Jaboatão dos Guararapes, 4/XII/1932, B. Pickel 3173 (IPA); Petrolina, 27/III/1991, P.E. Nogueira et al. 239 (ICN); Recife, 24/ XI/1933, B. Pickel 3439 (IPA).

Pertencente ao grupo Parviflora, esta espécie pode ser facilmente distinguida das demais aqui tratadas pela presença de tricomas globosos na gluma superior e lema inferior. Ao contrário do observado por Oliveira \& Valls (2001), esta espécie não apresentou grandes variações no seu hábito entre o material analisado para Pernambuco. Ocorre desde o México até o Paraguai. No Brasil está distribuída em quase todo o país. É aqui registrada pela primeira vez para Pernambuco. Foi coletada em solos arenosos do litoral e da caatinga. Segundo Filgueiras (1992), P. multicaule apresenta potencial forrageiro baixo e palatabilidade média.

19. Paspalum notatum Fluggé, Gram. Monogr., Paspalum: 106. 1810.

Perenes, cespitosas, rizomas curtos, superficiais. Colmos floríferos 30-40 cm compr., eretos; nós 1-2. Folhas concentradas na base; bainhas foliares glabras; lígulas $1 \mathrm{~mm}$ compr.; lâminas 6,5-12x0,6-0,8 cm, lanceoladas, agudas, não se estreitando em direção a base, glabras a pilosas. Inflorescências com 2 ramos, 4,5-7,5 cm compr., conjugados a subconjugados; inflorescências axilar ausente; ráquis glabras; ápice dos pedicelos glabros. Espiguetas 3-3,1x2-2,5 mm, ovais a elípticas, plano-convexas, agudas a obtusas, solitárias; gluma superior mais longa que o antécio superior, glabra, 5-nervada, nervuras conspícuas, cartácea; antécio inferior neutro, pálea ausente, lema inferior glabro, 5-nervado, nervuras conspícuas, cartáceo; antécio superior 2,6-2,8x1,9-2 $\mathrm{mm}$, oval, obtuso, coriáceo, estramíneo, finamente papiloso.

Material selecionado: BRASIL. Pernambuco: Petrolina, 18/VII/1988, L. Lima (CPATSA-1071); Recife, 15/ XI/2007, J.R. Maciel 541 (UFP).

Pertencente ao grupo Notata, esta espécie tem maior semelhança morfológica com Paspalum pumilum Nees, do mesmo grupo. Estas duas espécies se diferenciam das demais por suas inflorescências com dois ramos, raramente 3 , conjugados a subconjugados e espiguetas verdes. Entre si elas podem se diferenciar pelo tamanho das espiguetas que em $P$. notatum são tipicamente maiores. Além disso, Paspalum notatum possui rizomas fortemente arraigados ao solo e totalmente cobertos pelas bainhas velhas. Em Pernambuco $P$. notatum não faz parte dos elementos nativos e só é encontrada em jardins, cultivada como ornamental.

\section{Paspalum nutans Lam., Tabl. Encycl. 1: 175. 1791.} Fig. 19

Perenes, cespitosas, rizomas curtos, superficiais. Colmos floríferos 20-30 cm compr., decumbentes, nós 5-7. Folhas concentradas na base; bainhas foliares glabras; lígulas 1-2 mm compr.; lâminas $6-15 \times 0,5-1 \mathrm{~cm}$, lanceoladas, agudas, não se estreitando em direção à base, glabras a pilosas. Inflorescências com 1 ramo, 3-4,5 cm compr.; inflorescência axilar presente; ráquis glabras; ápice dos pedicelos glabros. Espiguetas 1,9-2x1,2-1,3 mm, obovais, plano-convexas, obtusas, pareadas; gluma superior atingindo metade do comprimento do antécio superior, glabra, 5-nervada, nervuras conspícuas, cartácea; antécio inferior neutro, pálea ausente ou presente, lema inferior glabro, 5-nervado, nervuras conspícuas, cartáceo; antécio superior 1,8-1,9x1,1-1,3 mm, elíptico, agudo, coriáceo, estramíneo, finamente papiloso.

Material selecionado: BRASIL. Pernambuco: Goiana, 5/X/2006, J.R. Maciel 365 (UFP, IPA); Recife, 18/XI/1924, A. Chase 7731 (MO); Serinhaém, 8/VII/2006, J.R. Maciel et al. 208 (UFP, IPA). 
Pertencente a Paspalum subg. Harpostachys, esta espécie se aproxima das demais por sua inflorescência com apenas um ramo e muitas inflorescências axilares. Pode ser confundida com P. oligostachyum Salzm. ex Steud. numa observação superficial, mas se diferencia facilmente desta por possuir apenas um ramo na inflorescência. Também pode se confundir com $P$. arenarium, da qual se diferencia por aspectos já discutidos. Quanto às demais espécies de $P$. subg. Harpostachys, P. nutans se separa por não apresentar espiguetas dispostas uma atrás da outra na ráquis. Ocorre desde Honduras até o Sul do Brasil. Foi coletada em bordas de mata, em solos arenosos e úmidos. Forrageira de baixa produtividade e apetecida pelo gado (Smith et al. 1982).

21. Paspalum oligostachyum Salzm. ex Steud., Syn. Pl. Glumac. 1: 23. 1853 [1855].

Fig. 20

Perenes, cespitosas, rizomas curtos, superficiais. Colmos floríferos 25-90 cm compr., inclinados; nós 4 . Folhas concentradas na base; bainhas foliares pilosas; lígulas $1 \mathrm{~mm}$ compr.; lâminas 6-17x0,6-1,7 cm, lanceoladas, agudas, não se estreitando em direção à base, pilosas. Inflorescências com 3-9 ramos, 1,5-9 cm compr., alternos; inflorescência axilar ausente; ráquis glabras; ápice dos pedicelos glabros. Espiguetas 1,9-2x1,3-1,5 mm, obovais, plano-convexas, agudas, pareadas; gluma superior de mesmo comprimento ou mais estreita e mais curta que o antécio superior, pubescente, 5-9-nervada, nervuras conspícuas, membranácea; antécio inferior neutro, pálea ausente, lema inferior glabro ou pubescente, 3-7-nervado, nervuras conspícuas, membranáceo; antécio superior 1,6-1,9x1,2-1,5 mm, oboval a suborbicular, agudo, coriáceo, estramíneo, papiloso.

Material selecionado: BRASIL. Pernambuco: Agrestina, 12/V/2007, J.R. Maciel et al. 474 (UFP, MO); Goiana, 3/X/2006, J.R. Maciel 353 (IPA, UFP); São Lourenço da Mata, 9/VIII/1932, B. Pickel 3087 (IPA).

Pertencente ao grupo Paniculata, Paspalum oligostachyum se caracteriza pelas espiguetas fortemente plano-convexas com glumas 5-9 nervadas. A variação no comprimento e número de ramos na inflorescência é relativamente grande, podendo ser encontrado espécimens com três a quatro ramos, condição mais comum, ou até nove ramos. Ocorre da Venezuela até o Brasil. No país é encontrada do Rio Grande do Norte até o Rio de Janeiro. Foi coletada em bordas de mata, em solos arenosos e úmidos. Sobre o seu potencial forrageiro pouco se conhece, mas possui boa produção de folhagem e parece resistente ao pisoteio.

\section{Paspalum orbiculatum Poir., Encycl. 5: 32. 1804.} Fig. 21

Perenes, estoloníferas. Colmos floríferos prostrados. Folhas regularmente distribuídas ao longo do colmo; bainhas foliares glabras; lígulas $0,3 \mathrm{~mm}$ compr.; lâminas $1,1-3 \times 0,3-$ $0,5 \mathrm{~cm}$, lanceoladas, agudas, não se estreitando em direção à base, glabras ou esparsamente pilosas. Inflorescências com 2 ramos, 0,8-1,5 cm compr., conjugados; inflorescência axilar ausente; ráquis glabras; ápice dos pedicelos glabros. Espiguetas 1x1 mm, orbiculares, plano-convexas, apiculadas, solitárias; gluma superior de mesmo comprimento do antécio superior, glabra, 2-nervada, nervuras conspícuas, membranácea; antécio inferior neutro, pálea ausente, lema inferior glabro, sem nervuras aparentes, membranáceo; antécio superior $0,9 \times 0,9 \mathrm{~mm}$, orbicular, obtuso, coriáceo, estramíneo, finamente papiloso.

Material selecionado: BRASIL. Pernambuco: São Lourenço da Mata, VII/1927, B. Pickel 1358 (IPA).

Dentre as espécies aqui tratadas $P$. orbiculatum é a única que possui colmos floríferos prostrados. Além do hábito, outros caracteres muito úteis na sua caracterização são a lâmina foliar atingindo até $3 \mathrm{~cm}$ compr., espigueta orbicular de $1 \mathrm{~mm}$, solitária e a gluma superior 2-nervada. Esta espécie pertence ao grupo informal Orbiculata. Ocorre desde o México até a Argentina. Foi coletada em bordas de mata em solo úmido. Segundo Rodriguez-Rodriguez (2003) é consumida por bovinos.

\section{Paspalum paniculatum L., Syst. Nat. Ed. 10, 2: 855.} 1759.

Fig. 22

Perenes, cespitosas, rizomas longos, profundos. Colmos floríferos 50-100 cm compr., eretos, nós 2-4. Folhas concentradas na base; bainhas foliares glabras ou pilosas, com tricomas concentrados próximos a margem; lígulas 0,5-1 mm compr.; lâminas 13-36x1,2-1,8 cm, lanceoladas, agudas, não se estreitando em direção à base, glabras a pilosas. Inflorescências com 9-29 ramos, 3-12 cm compr., alternos; inflorescência axilar ausente; ráquis glabras; ápice dos pedicelos glabros. Espiguetas 1,1-1,5x0,8-1,3 mm, orbiculares a suborbiculares, plano-convexas, obtusas, pareadas; gluma superior de mesmo comprimento ou mais curta que $o$ antécio superior, pilosa, tricomas tuberculados, 3-5-nervada, nervuras conspícuas, membranácea; antécio inferior neutro, pálea ausente, lema inferior piloso, tricomas tuberculados, 3-nervado, nervuras conspícuas, membranáceo; antécio superior 1-1,3x0,7-1,2 mm, subhemisférico, obtuso, cartáceo, estramíneo, liso a finamente papiloso.

Material selecionado: BRASIL. Pernambuco: Bonito, 10/XI/1967, E.C. Tenório 239 (IPA); Caruaru, 12/V/2007, J.R. Maciel et al. 463 (UFP, MO); Igarassu, 6/IV/2006, J.R. Maciel 127 (IPA, UFP); Recife, 3/I/1975, T. Sendulsky 1451 (SP); São Lourenço da Mata, 18/IV/2006, J.R. Maciel et al. 167 (IPA, MO).

Pertencente ao grupo Paniculata, é caracterizada pelas espiguetas orbiculares a suborbiculares de 1,1-1,5 mm compr. e gluma superior pilosa. $\mathrm{O}$ aspecto formado pelas diminutas espiguetas em panículas piramidais a distingue das outras espécies, mas a variação no comprimento dos ramos pode gerar problemas na identificação de alguns espécimens. 
Distribui-se amplamente desde os EUA até a Argentina. Foi coletada em bordas de mata e brejos de altitude. Fornece pastagem de boa qualidade, mas de baixa palatabilidade (Dombrowski 1989, Smith et al. 1982).

\section{Paspalum parviflorum Rhode ex Flüggé, Gram. Mono-} gr., Paspalum 98. 1810.

Fig. 23

Anuais, cespitosas, sem rizomas. Colmos floríferos 7-10 cm compr., eretos, nós 2-3. Folhas concentradas na base; bainhas foliares glabras ou pubescentes; lígulas $0,3-0,8 \mathrm{~mm}$ compr.; lâminas 1,5-3,5x0,2-0,3 cm, lineares, agudas, não se estreitando em direção à base, lanadas. Inflorescências com (2)3-4 ramos, 1-1,5 cm compr., alternos; inflorescência axilar ausente; ráquis com curtos tricomas nas margens ou escabras; ápice dos pedicelos glabros. Espiguetas 0,8-1x0,4-0,5 $\mathrm{mm}$, oblongas, plano-convexas, obtusas, solitárias; gluma superior de mesmo comprimento do antécio superior, glabra, 2-nervada, nervuras conspícuas, membranácea; antécio inferior neutro, pálea ausente, lema inferior glabro, 2-nervado, nervuras conspícuas, membranáceo; antécio superior 0,7 0,9x0,4 mm, oboval a oblongo, obtuso, coriáceo, alvo, liso.

Material selecionado: BRASIL. Pernambuco: Bezerros, 9/IV/2005, J.R. Maciel et al. 16 (IPA, UFP); Bonito, XI/2003, J.R. Maciel \& W. C. Silva 97 (IPA); Goiana, 12/ VIII/2007, J.R. Maciel 528 (IPA).

Espécie do grupo Parviflora, as plantas de P. parviflorum são ervas eretas e de pequeno porte, com no máximo $10 \mathrm{~cm}$ alt. e espigueta oblonga e obtusa. Os colmos floríferos são ramificados e geralmente são encontrados em pequenos tufos muito densos. Devido ao pequeno porte poderia se confundir com P. orbiculatum, mas esta possui espigueta orbicular e hábito prostrado muito característico. Ocorre desde o Panamá e Porto Rico até o Brasil e Bolívia. No Brasil é encontrada nas regiões Centro-Oeste, Norte e Nordeste. Foi coletada em solos arenosos de restinga e afloramentos rochosos de brejos de altitude. Não há informações disponíveis sobre seu potencial forrageiro, e das observações de campo pode se julgar que este não é muito grande.

\section{Paspalum pilosum Lam., Tabl. Encycl. 1: 175. 1791.} Fig. 24

Perenes, cespitosas, rizomas curtos, superficiais. Colmos floríferos 60-80 cm compr., eretos; nós 2-3. Folhas concentradas na base; bainhas foliares glabras ou pilosas; lígulas 1 mm compr.; lâminas 11-29x0,4-0,6 cm, linear-lanceoladas, agudas, não se estreitando em direção à base, pilosas. Inflorescências com 1 ramo, 8-10,5 cm compr.; inflorescência axilar presente; ráquis glabras; ápice dos pedicelos glabros. Espiguetas 2,5-3x1,2-2 mm, obovais, côncavo-convexos, agudas, pareadas; gluma inferior presente; gluma superior mais curta que o antécio superior, glabra, 5-nervada, nervuras conspícuas, cartácea; antécio inferior estaminado, pálea presente, lema inferior glabro, 5-nervado, nervuras conspícuas, cartáceo, sulcado; antécio superior 2-2,5x1,2-1,5 mm, oval, agudo, coriáceo, estramíneo, papiloso.

Material selecionado: BRASIL. Pernambuco: Moreno, 20/V/1980, L. Coradin et al. 2435 (IPA, IBGE).

Pertence a Paspalum subg. Harpostachys e é caracterizada pela inflorescência com um ramo, gluma inferior presente em pelo menos uma das espiguetas do par e gluma superior glabra, o que a diferencia de $P$. calliferum. Distribui-se desde o México até a Bolívia e Brasil, onde ocorre em praticamente todo o país. Aqui se faz o primeiro registro desta espécie para Pernambuco. Foi coletada em borda de mata. Segundo Filgueiras (1992) é considerada de médio valor forrageiro e média palatabilidade apesar de Dombrowski (1989) a considerar uma boa forrageira.

26. Paspalum pleostachyum Döll, Fl. Bras. 2(2): 58. 1877. Fig. 25

Perenes, cespitosas, rizomas longo, profundos. Colmos floríferos 70-120 cm compr., eretos; nós 3. Folhas concentradas na base; bainhas foliares glabras; lígulas $0,3 \mathrm{~mm}$ compr.; lâminas 12-20x0,6 cm, lineares, agudas, não se estreitando em direção à base, glabras. Inflorescências com 5-8 ramos, 8-10 cm compr., alternos; inflorescência axilar ausente; ráquis escabras; ápice dos pedicelos glabros. Espiguetas 2-2,2x1-1,3 mm, elípticas a obovais, plano-convexas, agudas, pareadas; gluma superior de mesmo comprimento ou maior que o antécio superior, glabra, 3-nervada, nervuras conspícuas, cartácea; antécio inferior neutro, pálea ausente, lema inferior glabro, 3-nervado, nervuras conspícuas, cartáceo; antécio superior 1,9-2×0,9-1 mm, elíptico, agudo, coriáceo, estamíneo, papiloso.

Material selecionado: BRASIL. Pernambuco: Itapissuma, 13/IV/2006, J.R Maciel et al.164 (IPA, UFP); Fernando de Noronha, 20/X/1955, D. Andrade-Lima 2225 (IPA); Garanhuns, 18/VIII/1969, E.C. Tenório 804 (IPA); Gravatá, 21/VIII/1969, E.C. Tenório 835 (IPA); Itambé, 18/IV/1969, M. Lira (IPA-16932).

Pertence ao grupo Caespitosa e inclui plantas que podem atingir até $120 \mathrm{~cm}$ de altura e espigueta de até $2,2 \mathrm{~mm}$ de comprimento, elíptica a oboval. Ocorre no Caribe e Brasil, onde tem registro para o Nordeste (Bahia, Ceará, Pernambuco, Piauí e Maranhão). Foi coletada na restinga em solos arenosos. Como possui hábito densamente cespitoso e pode ocorrer em populações muito numerosas, apresenta boa produção, mas talvez sua palatabilidade seja comprometida pela margem cortante das folhas. Em campo não foi observado indicativo de pastagem.

27. Paspalum plicatulum Michx., Fl. Bor.-Amer. 1: 45. 1803.

\section{Fig, 26}

Perenes, cespitosas, rizomas curtos, profundos ou ausentes. Colmos floríferos 40-120 cm compr., eretos ou decumbentes; nós 2-5. Folhas concentradas na base; bainhas folia- 
res glabras; lígulas 0,8-2 mm compr.; lâminas $12-52 \times 0,4-1,2$ $\mathrm{cm}$, lineares a linear-lanceoladas; agudas, não se estreitando em direção à base, glabras ou escabras. Inflorescências com 3-7 ramos, 2,8-7 cm compr.; inflorescência axilar ausente; ráquis glabras; ápice dos pedicelos glabros. Espiguetas 2-3x1,2-2 mm, elípticas a obovais, plano-convexas, obtusas, pareadas; gluma superior de mesmo comprimento ou mais curta que o antécio superior; glabra a pubescente, 5-nervada, nervuras conspícuas, membranácea; antécio inferior neutro, pálea ausente, lema inferior glabro, 3-5-nervado, nervuras conspícuas, membranácea; antécio superior 1,8-2,1x1-1,8 $\mathrm{mm}$, elíptico a oboval, obtuso, coriáceo, atro-purpúreo, brilhante, finamente papiloso.

Material examinado: BRASIL. Pernambuco: Cabo de Santo Agostinho, 15/VIII/1995, M. Alves et al. 5795 (UFP); Goiana, VII/1935, P.P. Mello 4030 (IPA); Igarassu, 6/IV/2006, J.R. Maciel 19 (IPA, UFP); Recife, 13/III/2006, J.R. Maciel \& D. Amorim 03 (IPA, UFP); São Lourenço da Mata, IX/1930, B. Pickel 2431 (IPA).

Espécie do grupo Plicatula, Paspalum plicatulum possui uma ampla variação morfológica. Para diferenciá-la das demais espécies ocorrente no estado recorre-se à sua duração perene, a presença de muitos nós e a inflorescência com aspecto quadrado de 3-7 ramos. O complexo taxonômico $P$. plicatulum é composto por diversas espécies perenes e cerca de 20 variedades (Oliveira \& Valls 2001). Ocorre desde os EUA até a Argentina. No Brasil é encontrada em todo o país. Foi coletada em bordas de mata. Seu potencial forrageiro é apontado com muitas boas referências para diversos aspectos, e pela diversidade de formas e ampla ocorrência sua aplicação em pastagens é muito promissora (Allem \& Valls 1987).

28. Paspalum pumilum Nees, Fl. Bras. Enum. Pl. 2(1): 52. 1829.

Fig. 27

Perenes, cespitosas, rizomas curtos, superficiais. Colmos floríferos 30-80 cm compr., eretos; nós 2-3. Folhas concentradas na base; bainhas foliares glabras ou pilosas; lígulas 1 mm compr.; lâminas 4-16x0,3-0,6 cm, oblongas a lineares, agudas, não se estreitando em direção à base, glabras ou pilosas na face adaxial. Inflorescências com 2(3) ramos, 2,3-8 cm compr., subconjugados; inflorescências axilar ausente; ráquis glabras; ápice dos pedicelos glabros. Espiguetas 1,7-2,1x1-1,2 mm, ovais a elípticas, plano-convexas, agudas, solitárias; gluma superior maior que o comprimento do antécio superior, glabra, 3-5-nervada, nervuras pouco a muito evidentes, cartácea; antécio inferior neutro, pálea ausente, lema inferior glabro, 3-5 nervado, nervuras pouco ou evidentes, cartáceo; antécio superior 1,4-1,8x1 mm, oboval ou elíptico, agudo, coriáceo, estramíneo, papiloso.

Material selecionado: BRASIL. Pernambuco: Bonito, 12/X/2006, J.R. Maciel 371 (UFP, IPA). Moreno, 20/V/1980, L. Coradin et al. 2438 (IPA, SP); Paulista, 17/XII/1958,
A. Sarmento 142 (PEUFR); Recife, 24/IX/1933, B. Pickel 3441 (IPA); Serinhaém, 20/VII/2006, J.R. Maciel et al. 219 (UFP, IPA).

Pertencente ao grupo Notata, esta espécie pode ser confundida com $P$. multicaule que se caracteriza pelos tricomas globosos na gluma superior e lema inferior. Também é semelhante a Paspalum notatum, separando-se pelas espiguetas menores e pelos rizomas achatados contra o solo, formando touceiras circulares. Ocorre desde as Antilhas até a Argentina. No Brasil ocorre desde o Pará, região Nordeste até o Sul. Foi coletada em locais muito úmidos em bordas de mata ou margens de cachoeiras. Seu potencial forrageiro é destacado por Barreto (1957), porém não foi possível confirmar seu uso por animais nas observações de campo realizadas.

29. Paspalum repens Berg., Acta Helv. Phys.-Math. 7 : 129. 1762.

Fig. 28

Perenes, cespitosas, rizomas longos, profundos. Colmos floríferos até $200 \mathrm{~cm}$ compr., decumbentes, nós muitos. Folhas regularmente distribuídas ao longo do colmo; bainhas foliares pubescentes; lígulas 1,5-2 mm compr.; lâminas $10-25 \times 0,6-1 \mathrm{~cm}$, lanceoladas, agudas, não se estreitando em direção a base, pubescentes. Inflorescências com 20-50 ramos, 5-10 cm compr., alternos; inflorescência axilar ausente; ráquis glabras, foliáceas; ápice dos pedicelos glabros. Espiguetas 1,9-2,1x0,9-0,1 mm, elípticas, plano-convexas, acuminadas, solitárias; gluma superior mais longa que o antécio superior, glabra, 2-nervada, nervuras conspícuas, membranácea; antécio inferior neutro, pálea ausente, lema inferior glabro, plano, 2-nervado, nervuras conspícuas, membranáceo; antécio superior 1,7-1,8x0,9-1 mm, elíptico, agudo, cartáceo, estramíneo, finamente papiloso.

Material selecionado: BRASIL. Pernambuco: Belém do São Francisco, 19/IX/1987, J.E. Paula 3007 (UB); Cabo de Santo Agostinho, 4/XII/1976, J.E. Paula \& J.L.H. Alves 727 (UB).

Espécie pertencente ao grupo Dissecta, caracteriza-se pela ráquis foliácea portando espiguetas solitárias. Dentre todas é a única com hábito aquático e presença de colmos inflados que, após o processo de herborização, tornam-se facilmente reconhecíveis por murcharem quando desidratados. Ocorre desde os EUA até a Argentina e no Brasil é encontrada em todo o país. Segundo Zuloaga \& Morrone (2005), P. repens é uma forrageira nativa muito apetecida pelos animais.

30. Paspalum scutatum Nees ex Trin., Gram. Panic. 105. 1826.

Fig. 29

Anuais, cespitosas, sem rizomas. Colmos floríferos 25$40 \mathrm{~cm}$ compr., eretos; nós 2-3. Folhas concentradas na base; bainhas foliares pilosas; lígulas 1-2 mm compr.; lâminas 3-8 $\times 0,3-0,9 \mathrm{~cm}$, lanceoladas, agudas, não se estreitando em direção à base, pilosas. Inflorescências com 2-4 ramos, 
2-3,5 cm compr., alternos; inflorescência axilar ausente; ráquis glabras; ápice dos pedicelos glabros. Espiguetas 1,92,6x1,8-2,2 mm, escutiformes, plano-convexas, apiculadas, pareadas; gluma superior mais longa que o antécio superior, glabra, 5-9-nervada, nervuras conspícuas, membranácea; antécio inferior neutro, pálea ausente, lema inferior glabro, nervuras inconspícuas, membranáceo; antécio superior 1,51,8x1,4-1,6 mm, oboval, obtuso, coriáceo, estramíneo, liso a finamente papiloso.

Material selecionado: BRASIL. Pernambuco: Araripe, 24/V/1980, L. Coradin et al. 2562 (IPA); Buíque, 5/VIII/2006, J.R. Maciel et al. 345 (UFP, MO); Mirandiba, 30/III/2006, J.R. Maciel et al. 136 (UFP, MO); Petrolina, 18/IV/1971, E.P. Heringer et al. 146 (IPA, PEUFR, SP).
Espécie facilmente reconhecida por sua espigueta escutiforme. Embora possua características da espigueta muito típicas, foi indicada por Chase (dados não publicados) como relacionada à Paspalum fimbriatum. Espécie endêmica aos Domínios do Semi-Árido brasileiro é encontrada em solos arenosos da caatinga. Seu potencial forrageiro nunca foi discutido, mas é provável que ele não seja elevado por ser anual e com ciclo muito curto.

\section{Paspalum vaginatum Sw., Prodr.: 21. 1788.}

Fig. 30

Perenes, estoloníferas. Colmos floríferos até $40 \mathrm{~cm}$ compr., eretos; nós muitos. Folhas regularmente distribuídas ao longo do colmo; bainhas foliares glabras; lígulas $1 \mathrm{~mm}$ compr.; lâminas 4-10x0,3-0,4 cm, lineares, agudas, não se
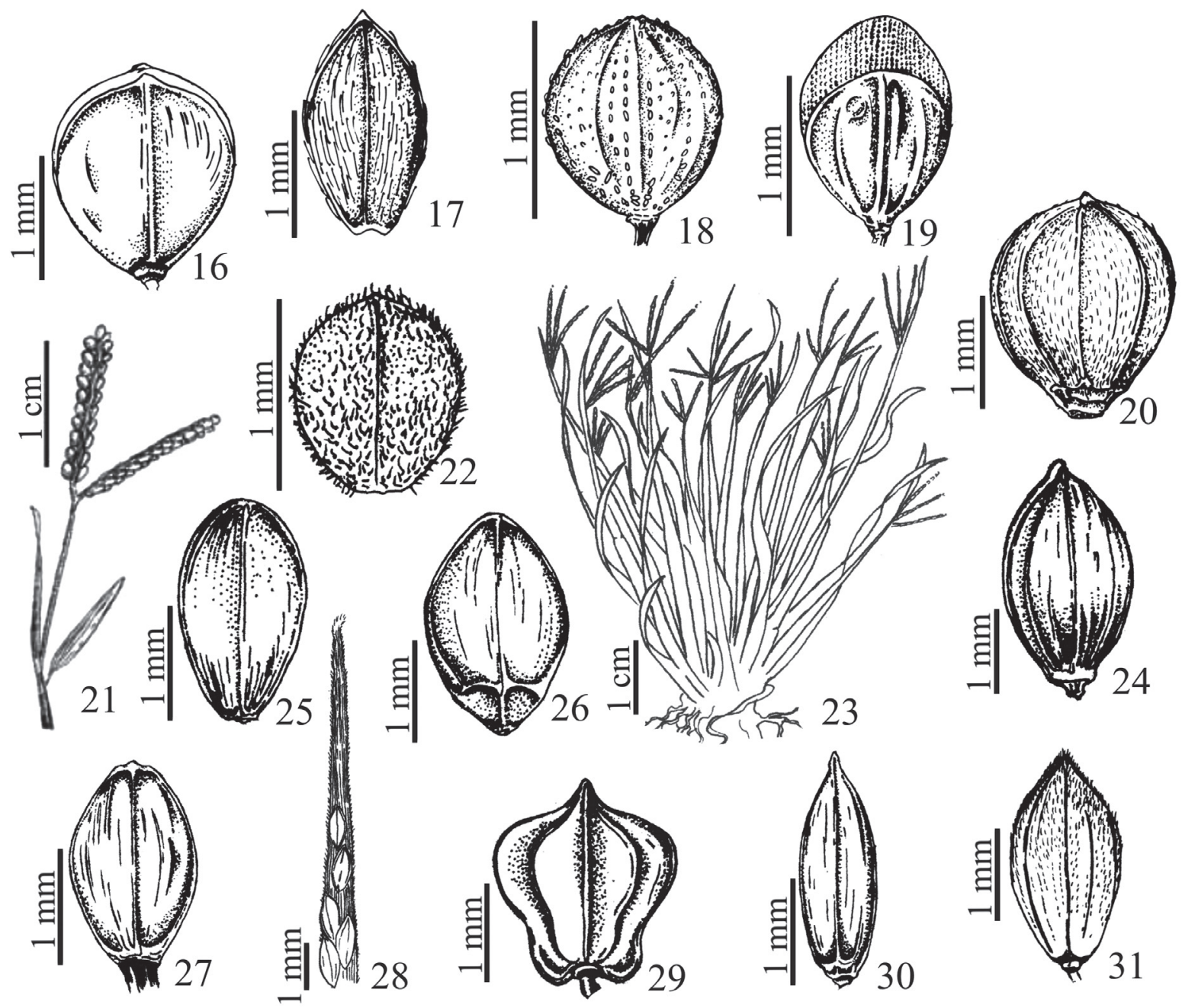

Figuras 16-31. Espigueta em vista da gluma superior: 16. Paspalum molle Poir. (B. Pickel 2357). 17. Paspalum millegrana Schrad. (J.R. Maciel et al. 18). 18. Paspalum multicaule Poir. (B. Pickel 3439). 19. Paspalum nutans Lam. (J.R. Maciel 365). 20. Paspalum oligostachyum Salzm. ex Steud. (J.R. Maciel et al. 220). Fragmento do colmo florífero: 21. Paspalum orbiculatum Poir. (B. Pickel 1358). Espigueta em vista da gluma superior: 22. Paspalum paniculatum L. (J.R. Maciel 127). Hábito: 23. Paspalum parviflorum Rhode ex Flüggé (Andrade-Lima 2083). Espigueta em vista da gluma superior: 24 . Paspalum pilosum Lam. (L. Coradin et al. 2435). 25. Paspalum pleostachyum Döll (J.R. Maciel 164). 26. Paspalum plicatulum Michx. (J.R. Maciel 361). 27. Papalum pumilum Nees. (J.R. Maciel et al. 219). Detalhe da ráquis: 28. Paspalum repens Berg. (L.P. Xavier 1491). 29. Espigueta em vista da gluma superior: Paspalum scutatum Nees (J.R. Maciel et al. 144). 30. Paspalum vaginatum Sw. (E.C. Tenório 49). 31. Paspalum virgatum L. (J.R. Maciel 168). 
estreitando em direção à base, glabras. Inflorescências com 2(3) ramos, 3,5-5 cm compr., subconjugados; inflorescência axilar ausente; ráquis glabras; ápice dos pedicelos glabros. Espiguetas 3-3,1x1,2-1,5 mm, ovais, plano-convexas, acuminadas, solitárias; gluma superior mais longa que o antécio superior, glabra, 3-5-nervada, nervuras conspícuas ou inconspícuas, cartácea; antécio inferior neutro, pálea ausente, lema inferior glabro 3-5-nervado, nervuras conspícuas, cartáceo; antécio superior 2,5-2,8x1-1,2 mm, oval a elíptico, agudo, coriáceo, estramíneo, estriado.

Material selecionado: BRASIL. Pernambuco: Arcoverde, 18/IX/1969, E. C. Tenório 1097 (IPA, PEUFR).

Paspalum vaginatum pertence ao grupo Disticha e possui claras relações morfológicas com $P$. distichum, diferenciando-se por aspectos já discutidos. Amplamente distribuída desde os EUA até a Argentina, no Brasil é encontrada em todo o país. Foi coletada em solo arenoso de praia. Barreto (1957) citou seu valor forrageiro como regular. Devido aos seus longos estolhos, pode contribuir na fixação de dunas e solos castigados pelo mar.

\section{Paspalum virgatum L., Syst. Nat. (ed. 10) 2: 855.1759.} Fig. 31

Perenes, cespitosas, rizomas longos, profundos. Colmos floríferos 120-170 cm compr., eretos, nós 2. Folhas concentradas na base; bainhas foliares glabras; lígulas 2-4 mm compr.; lâminas 38-57,5x1,2-1,4 cm, lineares a linearlanceoladas, agudas, não se estreitando em direção à base, glabras. Inflorescências com 11-18 ramos, 5-15 cm compr., alternos; inflorescência axilar ausente; ráquis esparsamente pilosas nas margens, escabras; ápice dos pedicelos glabros. Espiguetas 2,8-3,1x1,8-2,1 mm, obovais, plano-convexas, apiculadas, pareadas; gluma superior mais longa que $\mathrm{o}$ antécio superior, pubescente, 5-nervada, nervuras conspícuas, cartácea; antécio inferior neutro, pálea ausente, lema inferior glabro a pubescente, 5-nervado, nervuras conspícuas, cartáceo; antécio superior 2,5-3×1,8-2 mm, oboval, obtuso, coriáceo, castanho-claro, opaco, papiloso.

Material selecionado: BRASIL. Pernambuco: Brejo da Madre de Deus, 28/XII/1966, E.C. Tenório 222 (IPA); Moreno, 18/IX/2003, M.B. Costa e Silva et al. REC 172 (IPA); São Lourenço da Mata, 18/IV/2006, J.R. Maciel et al. 171 (IPA, UFP).

Espécie caracterizada pelo porte alto e colmos muito robustos, que a destaca das demais espécies de Paspalum ocorrentes em Pernambuco. Pertence ao grupo Virgata. Pelo porte poderia ser confundida com $P$. millegrana, mas esta espécie se diferencia pela espigueta oboval, gluma superior glabra e antécio superior estramíneo. Ocorre desde o México e Caribe até Argentina e Bolívia. No Brasil ocorre em quase todo o país. Foi coletada em borda de mata, em solos sujeitos a alagamento temporário. Dombrowski (1989) a cita como forrageira de baixo valor, no entanto Allem \& Valls (1987) apontam que seu uso pode ser muito promissor.

\section{Agradecimentos}

Os autores agradecem aos curadores dos herbários visitados em particular à Dra. Rita de Cássia Araújo Pereira (IPA) e Marlene Barbosa (UFP), que gentilmente permitiram o acesso a estrutura dos herbários IPA e UFP para a condução da maior parte deste estudo; às Dras. Silvia Terezinha Sfoggia Miotto e Reyjane Patrícia de Oliveira, assim como aos dois revisores anônimos, pelos valiosos comentários. O primeiro autor agradece a concessão de Bolsa de Mestrado do Programa Taxonomia CNPq/MCT. Este estudo contou com o apoio financeiro da Fundação O Boticário de Proteção à Natureza.

\section{Referências bibliográficas}

Allem, A.C. \& Valls, J.F.M. 1987. Recursos forrageiros nativos do pantanal mato-grossense. Brasília, EMBRAPA.

Andrade-Lima, D. 1960. Estudos fitogeográficos de Pernambuco. Arquivo do Instituto de Pesquisas Agronômicas de Pernambuco 5: 305-341

Barreto, I.L. 1957. Las especies de Paspalum con dos racimos conjugados en Rio Grande del Sur (Brasil). Revista Argentina de Agronomia 24: 89-117.

Barreto, I.L. 1965. As espécies afins a Paspalum corcovadense Raddi (Gramineae) no Rio Grande do Sul. Revista da Faculdade de Agronomia e Veterinária 7: 197-210.

Barreto, I.L. 1966. Las especies afines a Paspalum quadrifarium (Gramineae) en la América del Sur de clima subtropical y templado. Darwiniana 14: 130-155.

Chase, A. 1929. The North American species of Paspalum. Contributions from the United States National Herbarium 28: 1-310.

Clayton, W.D. \& Renvoize, S.A. 1986. Genera graminum: grasses of the world. Her Magesty's Stationary Office. London, Kew Bulletin Aditional Series, 13

Denham, S.S. 2005. Revisión sistemática del subgénero Harpostachys de Paspalum (Poaceae: Panicoideae: Paniceae). Annals of the Missouri Botanical Garden 92: 463-532.

Dombrowski, L.T.D. 1989. Gramíneas do Paraná. Londrina, IAPAR.

Filgueiras, T.S. 1992. Gramíneas forrageiras nativas no Distrito Federal, Brasil. Pesquisa Agropecuária Brasileira 27: 1103-1111.

Holmgren, P.K., Holmgren, N.H. \& Barnett, L.C. 8 ed. (eds.). 2003. Index Herbariorum Part I: the herbaria of theWorld. New York, New York Botanical Garden. Disponível em: http://www.nybg,org/bsci/ih . Acesso em: 21 de dezembro de 2006.

Longhi-Wagner, H.M. 2001. Poaceae. Pp. 1-9. In: H. M. Longhi-Wagner; V. Bittrich; M. G. L. Wanderley \& G. J. Shepherd (eds). Flora Fanerogâmica do Estado de São Paulo. São Paulo, Hucitec. v. 1.

Nascimento, M.P.S.C.B. \& Renvoize, S.A. 2001. Gramíneas Forrageiras Naturais e Cultivadas na Região Meio-Norte. Teresina, Embrapa Meio-Norte.

Oliveira, R.C. \& Valls, J.F.M. 2001. Paspalum. Pp. 191-228. In: H.M. Longhi-Wagner; V. Bittrich; M.G.L. Wanderley \& G.J. Shepherd (eds). Flora Fanerogâmica do Estado de São Paulo. São Paulo, Hucitec. v. 1.

Pupo, N.I.H. 1989. Manual de pastagens e forrageiras: formação, conservação e utilização. Campinas, Instituto Campineiro de Pesquisas Agrícolas.

Renvoize, S.A. 1984. The grasses of Bahia. Kew, Royal Botanic Gardens. Rodriguez-Rodriguez, H.J. 2003. Sección Orbiculata (Nash) Rodriguez-R. del género Paspalum L. (Poaceae) en Venezuela. Ernstia 13: 105-115.

Smith, L.B., Wasshausen, D. \& Klein, R. 1982. Gramíneas. In: Flora Ilustrada Catarinense. R. Reitz, (ed.). Itajaí, Herbário Barbosa Rodrigues. vol. 3..

Souza-Chies, T.T., Essi, L., Rua, G.H., Valls, J.F.M. \& Miz, R.B. 2006. A preliminary approach to the phylogeny of the genus Paspalum (Poaceae). Genetica 126: 15-32.

Zuloaga, F.O. \& Morrone, O. 2005. Revisión de las especies de Paspalum para América del Sur Austral (Argentina, Bolívia, Sur del Brasil, Chile, Paraguay y Uruguay). Monographs in Systematic Botany from Missouri Botanical Garden 102: 1-297. 


\author{
Anexo I \\ 1. Paspalum arenarium \\ 2. P. atratum \\ 3. P. calliferum \\ 4. P. clavuliferum \\ 5. P. conjugatum \\ 6. P. convexum \\ 7. P. corcovadense \\ 8. P. coryphaeum
}

\author{
9. P. denticulatum \\ 10. P. distichum \\ 11. P. divergens \\ 12. P. fimbriatum \\ 13. P. gardnerianum \\ 14. P. maritimum \\ 15. P. melanospermum \\ 16. P. millegrana
}

17. P. molle

18. P. multicaule

19. P. notatum

20. P. nutans

21. P. oligostachyum

22. P. orbiculatum

23. P. paniculatum

24. P. parviflorum

\author{
25. P. pleostachyum \\ 26. P. pilosum \\ 27. P. plicatulum \\ 28. P. pumilum \\ 29. P. repens \\ 30. P. scutatum \\ 31. P. vaginatum \\ 32. P. virgatum
}

\section{A. Chase 7731 (20);}

A. Melquíades \& G. J. Bezerra 122 (16);

A. Sarmento 134 (5), 142 (28), 191 (14), 201 (7), 209 (5);

B. Pickel 68 (16), 79 (14), 81 (32), 91 (17), 696 (23), 701 (23), 1197 (21),1266 (5), 1346 (21), 1358 (22), 1362 (14), 1395 (27), 1397 (32), 1402 (27), 1561 (8), 1564 (16), 1565 (5), 1574 (14), 1583 (17), 1584 (4), $1586(27), 1605$ (4), 1607 (32), 1617 (14), 1618 (21), 1619 (23), 1995 (14), 2004 (23), 2210 (23), 2340 (8), 2344 (32), 2357 (17), 2369 (14), 2372 (23), 2431 (27), 2559 (13), 2597 (32), 2598 (8), 2629 (32), 2738 (17), 2930 (16), 2969 (8), 3028 (32), 3029 (32), 3087 (31), 3173 (18), 3254 (1), 3258 (32), 3266 (8), 3277 (23), 3439 (18), 3440 (1), 3441 (28), 3529 (8), 3760 (31), 3773 (11), 3777 (11), 3791 (21), 3792 (14), 4263 (6), 7124 (6), (IPA-1207) (21), (IPA-1203) (23), (IPA-1205) (27);

D. Andrade-Lima 554 (6), 2208 (25), 2225 (25), 2233 (14), 2236 (14), 2083 (24), 4126 (27), 4147 (25), 5355 (25), 5375 (25), 8045 (12), 9232 (4), 9478 (12), 9476 (12), (PEUFR-1337) (32);

D. Andrade Lima et al. 9232 (4), 9681 (14);

D. Andrade-Lima \& M. Costa 185, 202;

E. B. Correia (IPA 15046) (3);

E. B. Ferraz \& R. Pereira 12 (12);

E. C. Tenório 93 (15), 96 (21), 131 (21), 135 (32), 139 (6), 161 (27), 196 (17), 222 (32), 226 (7) 236 (21), 239 (23), 332 (9), 337 (9), 674 (14), 676 (5), 668 (25), 733 (13), 746 (17), 758 (21), 759 (17), 764 (21), 774 (17), 782 (21), 793 (21), 795 (23), 799 (21), 803 (3), 807 (6), 804 (25), 809 (21), 828 (21), 833 (25), 835 (25), 847 (30), 853 (30), 855 (12), 864 (12), 895 (1), 901 (15), 913 (19), 931 (30), 961 (25), 971 (30), 986 (6), 969 (1), 987 (12), 989 (12), 1026 (30), 1032 (12), $1036(30), 1068$ (30), 1080 (31), 1087 (10), 1097 (31), 1110 (1), 1128 (14), 1139 (1), 1155 (30), 1172 (6), 1183 (5), 1192 (16), 1197 (16), 1209 (14), 1212 (16), 1221 (14), 1244 (16), $1250(5), 1252$ (6), $1258(14), 1272$ (5), 1274 (14), 1291 (14), 1304 (14), 1306 (31), 1312 (6), 1317 (14), 1325 (23), 1326 (6), 1327 (5), 1333 (5), 1336 (32), 1352 (32);

E. Inácio et al. 230 (14);

E. P. Heringer et al. 146 (30), 209 (12), 319 (30), 445 (15), 446 (4), 490 (12);

F. Araújo 17(4), 46 (30), 80 (12), 111 (30), 159 (12);

F. Gallindo 168, 186 (14), 199 (31);

G. Guilde 4161 (10);
G. V. C. Silva (IPA-50189) (5);

I. A Falcão et al. 990 (16);

I. Pontual (PEUFR-9703) (30);

J A Siqueir-Filho \& G. S. Baracho 673/626 (23);

J. Cantarelli 704 (14);

J. E. Paula 3007 (29);

J. E. Paula \& J. L. H. Alves 726 (29), 727 (29):

J. F. M. Valls 1080 (14);

J. R. Maciel 1 (5), 05 (23), 06 (5), 18 (16), 19 (6), 124 (14), 125 (14), 126 (23), 127 (23), 128 (23), 131 (15), 212 (6), 371 (28), 459 (6), 466 (6), 541 (19);

J. R. Maciel et al. 16 (24), 19 (27), 24 (5), 130 (12), 131 (15), 132 (12), 136 (30), 144 (30), 147 (12), 149 (30), 153 (14), 154 (1), 155 (14), 156 (14), 157 (14), 158 (14), 159 (14), $160(14), 162(14), 164(26), 165(11), 166(2) 167$ (23), 168 (32), 169 (32), 170 (27), 171 (32), 172 (17), 189 (30), 195 (30), 208 (20), 214 (21), 219 (28), 220 (21), 221 (14), 222 (28), 345 (30), 346 (1), 353 (21), 355 (14), 361 (27), 365 (20), 369 (2), 371 (28), 372 (16), 377 (16), 388 (14), 399 (30), 400 (15), 409 (15), 410 (12), 426 (15), 427 (15), 448 (15), 458 (17), 460 (17), 463 (23), 469 (30), 474 (21) 496 (4), 509 (30), 525 (11), 527 (11), 528 (24);

J. R. Maciel \& D. Amorim 01 (2), 02 (14), 03 (27), 04 (14), 08 (1), 09 (1), 166 (2);

J. R. Maciel \& W. C. da Silva 53 (5), 97 (24);

L.Coradin et al. 1241 (30), 1290 (12), 1291 (30), 1353 (30), 1378 (12), 1390 (12), 1400 (12), 2435 (25), 2436 (14), 2437 (6), 2438 (28), 2443 (19), 2467 (10), 2472 (6), 2487 (12), 2492 (30), 2500 (8), 2562 (30);

L. Lima (CPATSA-1071) (19);

M. Alves et al. 5495 (27), 5795 (27);

M. A. P. Florêncio (UFP-3856) (5);

M. B. Costa e Silva et al. REC 172 (32);

M. Coelho (IPA-15045) (5), (IPA-15044) (14);

M. Lira (IPA-16932);

M. Luceño (UFP-11810) (5);

M. Magalhães (IPA-12618) (24);

M. Mattos et al. 40 (16);

O C. Lira (UFP-02672) (13);

P. E. Nogueira et al. 239 (18), 278 (30);

P. Ferreira 49 (31);

P. Luetzelburg 26304 (5), 26304 (5);

P. P. Mello 4030 (27); 
R. Galindo 01 (5), 23 (5);

R. Pimentel 03 (16), 04 (5);

S. Tavares 624 (14);

Tereza et al. 10 (16);

T. Amélia 10 (5);

T. Sendulky 145 (23), 1439 (14), 1443 (14), 1451 (23), 1455 (14);
Valderes 06 (12);

V. C. Lima \& F. Gallindo 74 (15);

V.C. Lima et al. 12 (12);

V. Sobrinho (IPA-99) (14), (IPA-3) (16), (IPA-253) (31). 